\title{
Opposite Effects of ENSO on the Rainfall over the Northern and Equatorial Great Horn of Africa and Possible Causes
}

\author{
K. Abebe Kiflie ${ }^{1,2}$ and Li Tao $\mathbb{i D}^{1}$ \\ ${ }^{1}$ School of Atmospheric Sciences, Nanjing University of Information Science and Technology, Nanjing, China \\ ${ }^{2}$ Addis Ababa Science and Technology University, P.O. Box 16417, Addis Ababa, Ethiopia \\ Correspondence should be addressed to Li Tao; taoli@nuist.edu.cn
}

Received 14 October 2019; Revised 29 June 2020; Accepted 3 August 2020; Published 3 September 2020

Academic Editor: Roberto Coscarelli

Copyright $\odot 2020 \mathrm{~K}$. Abebe Kiflie and Li Tao. This is an open access article distributed under the Creative Commons Attribution License, which permits unrestricted use, distribution, and reproduction in any medium, provided the original work is properly cited.

\begin{abstract}
In this study, we explore the possible mechanism of opposite ENSO effects on summer rainfall in the JJAS region (northern GHA) and autumn rainfall in the OND region (equatorial GHA). The two regions are identified based on the spatial distribution of high seasonal fractions of annual rainfall for the period 1979-2016. The summer rainfall over the JJAS region is negatively correlated with ENSO. It is because the warm Niño3.4 SST triggers zonal wave one pattern in tropics and forces upper-level westerly anomaly and the low-level easterly anomaly over tropical Africa. Thus, the weakened upper-level Tropical Easterly Jet (TEJ) and the lowlevel westerly over the JJAS region result in deficient rainfall during JJAS over the northern GHA. For the autumn rainfall variability over the equatorial GHA, IOD is a pivotal factor. But, autumn rainfall anomalies are far greater in ENSO and IOD coexisting years than those in IOD alone years. In other words, ENSO has a significant impact on the autumn rainfall over the equatorial GHA by means of IOD. It is because the warming SST, which is fully developed over western Indian Ocean (IO) in autumn of ENSO developing year, causes low-level convergence over the equatorial GHA and enhances upper-level easterly over tropical Africa. Those conditions are favorable for abundant rainfall over the equatorial GHA in autumn.
\end{abstract}

\section{Introduction}

The economics of the Great Horn of Africa (GHA, including five countries, namely, Ethiopia, Eritrea, Djibouti, Somalia, and Kenya; Figure 1) mainly depend on rainfed agriculture, which is highly influenced by seasonal rainfall magnitude (e.g., [1] and is vulnerable to the impacts of the climate variability. In the region, extreme weather events such as floods and droughts are frequent and often impact negatively on crop production [2] [3-5].

According to IGAD Climate Prediction and Application Centre (ICPAC), the seasons in the GHA are categorized as winter (January-February, JF), spring (March-May, MAM), summer (June-September, JJAS), and autumn (OctoberDecember, OND). The seasonal cycle of rainfall over northern GHA, including Ethio-Sudanese border, and central and northern Ethiopia and Eritrea, presents one main rainy season: JJAS. While the seasonal cycle of rainfall over southern GHA, including south-eastern Ethiopia,
Kenya, and Somalia, presents two main rainy seasons: one is MAM, and the other is OND.

Many studies suggested the variability of precipitation over this torrid zone has been driven by different factors, such as the migration of the intertropical convergence zone (ITCZ) from the eastern Sahel to the southern parts of Kenya $[6,7]$, the Indian Ocean Dipole $[3,4,8,9]$, El Niño Southern Oscillation [4, 6, 10-14], and the East African Low-Level Jet [15]. Diro et al. [11] investigated the correlation between global SST and rainfall in different regions of Ethiopia. They showed that JJAS rainfall in Ethiopia is negatively correlated with ENSO. Only the south-eastern part of Ethiopia displays a weak positive correlation to equatorial East Pacific SST. Based on the sensitivity experiments driven only with equatorial Pacific SST anomalies, Diro et al. [11] and Gleixner et al. [12] suggested that a slowdown of the whole Indian monsoon system with a weaker upper-level Tropical Easterly Jet (TEJ) and a weaker low-level East African jet causes a dry summer over Ethiopia in El Niño year. While 


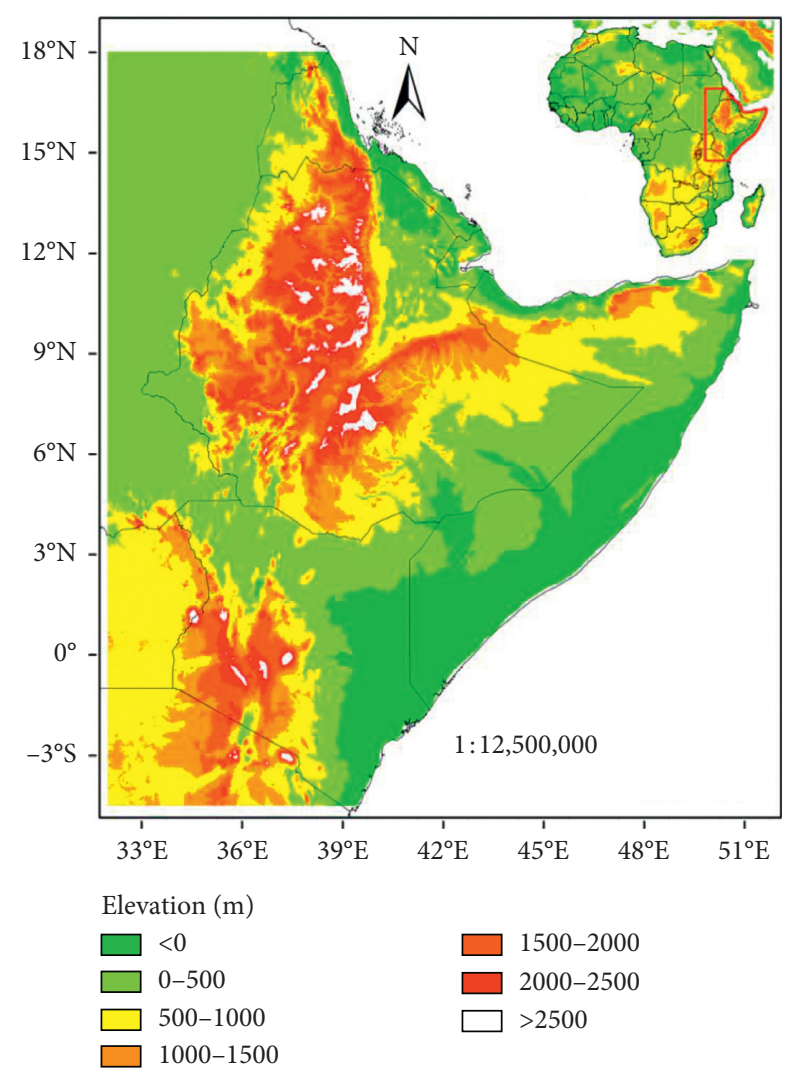

Figure 1: The study domain $\left(4.5^{\circ} \mathrm{S}-18^{\circ} \mathrm{N}, 32^{\circ}-51.5^{\circ} \mathrm{E}\right)$ and its topographic elevation $(\mathrm{m})$.

others (e.g., $[8,16])$ found that the Indian Ocean dipole (IOD) plays a dominant role in the OND rainfall variability in equatorial East Africa, and the correlation between ENSO and autumn rainfall is insignificant when the IOD influence is excluded. So far, many studies examined the influence of ENSO or the IOD on the rainfall over East Africa. Very few authors compare the different dynamical processes of the influence of ENSO on the seasonal rainfall in different regions of the GHA. In this study, we identify two rainfall regions over the GHA: JJAS region and OND region based on the spatial distribution of high seasonal fractions of annual rainfall find that the correlation of JJAS rainfall in northern GHA with Niño3.4 SST is opposite with the OND rainfall in equatorial GHA with Niño3.4 SST. We will explore the mechanism and draw some conclusions.

The rest of the study is organized as follows: Section 2 describes the data and methods. Section 3 gives dominant modes of the GHA seasonal rainfall, the different response of atmospheric circulations between JJAS and OND to Niño3.4 SST, and analyzes the different dynamical processes responsible for the opposite correlation of summer rainfall and autumn rainfall in East Africa with Niño3.4 SST. The main conclusions and discussions are given in Section 4.

\section{Data and Methods}

In this study, we use the climatic research unit (CRU) monthly precipitation constructed by the Climate Anomaly
Method from the UK Met Office [17]. The monthly Outgoing Longwave Radiation (OLR) data are obtained from the National Oceanic and Atmospheric Administration [18]. The monthly mean SST data are obtained from the Hadley Centre's Sea Ice and SST dataset [19]. The monthly mean wind, geopotential height, and seal level pressure fields are obtained from the National Centers for Environmental Prediction (NCEP) and National Center for Atmospheric Research (NCAR) reanalysis data [20]. All these datasets during 1979-2016 are analyzed in this study.

Indian Ocean dipole mode index (DMI) [21-23] and Niño3.4 SST indices are obtained from http://www.bom.gov. au/climate/iod/. A total of 7 positive IOD years $(1982,1983$, 1994, 1997, 2006, 2012, and 2015) and 8 negative IOD years (1981, 1984, 1989, 1992, 1996, 1998, 2010, and 2016) are defined when the DMI index exceeds 0.8 and -0.8 standard deviation, respectively. A total of 7 El Niño years (1982, 1987, 1991, 1997, 2002, 2009, and 2015) and 7 La Niña years (1984, 1988, 1998, 1999, 2007, 2010, and 2011) are defined when Niño3.4 index exceeds 0.8 and -0.8 standard deviation, respectively. About half of IOD events are related to ENSO events. Some of positive IOD years are concurrent with El Niño years; some of negative IOD years are concurrent with La Niña years. During 1979-2016, there are 3 El Niño and positive IOD (pIOD) coexisting years (1982, 1997, and 2015) and 3 La Niña and negative IOD (nIOD) coexisting years (1984, 1998, and 2010); 4 El Niño alone years (1987, 1991, 2002, and 2009) and 4 La Niña alone years (1988, 1999, 2007, and 2011); 4 positive IOD alone years $(1983,1994,2006$, and 2012) and 5 negative IOD alone years $(1981,1989,1992$, 1996, and 2016).

The different seasonal rainfall regions are defined based on the seasonal fraction to annual rainfall for the JF, MAM, JJAS, and OND seasons, respectively (Figure 2). Two domains $\left(36-44.5^{\circ} \mathrm{E}, 2-7^{\circ} \mathrm{N}\right)$ and $\left(44.5-50.5^{\circ} \mathrm{E}\right.$, $4-11.5^{\circ} \mathrm{N}$ ) together are defined as MAM region. The MAM region mainly covers southeastern Ethiopia and northern Somali. The domain $\left(32-42^{\circ} \mathrm{E}, 7-18^{\circ} \mathrm{N}\right)$ is defined as JJAS region. The JJAS region mainly covers most of Ethiopian region and southern Sudan. Two domains $\left(37-40.5^{\circ} \mathrm{E}\right.$, $\left.3.5^{\circ} \mathrm{S}-1.5^{\circ} \mathrm{N}\right)$ and $\left(40.5-46^{\circ} \mathrm{E}, 1.5-5.5^{\circ} \mathrm{N}\right)$ together are defined as the OND region. The OND region mainly covers southern Kenya and southern Somali. The seasonal rainfall of the selected regions accounts for more than $45 \%$ of annual rainfall.

Because the MAM seasonal rainfall has a weak relationship with the SST anomalies in the tropical Indian and Pacific Oceans (figures not shown here), we only examine the impact of ENSO on summer rainfall over the JJAS region and autumn rainfall over the OND region. To address these issues, the correlation between JJAS seasonal rainfall and OND seasonal rainfall anomalies in their domains with monthly SST for a sample size of 38 years is examined. In order to determine atmospheric circulation pattern associated with SST anomalies, atmospheric circulation composites of El Niño (or El Niño alone; pIOD; pIOD alone; El Niño and pIOD coexisting) year minus La Niña (or La Niña alone; nIOD; nIOD alone; La Niña and nIOD coexisting) were studied, which provides a deep understanding of 


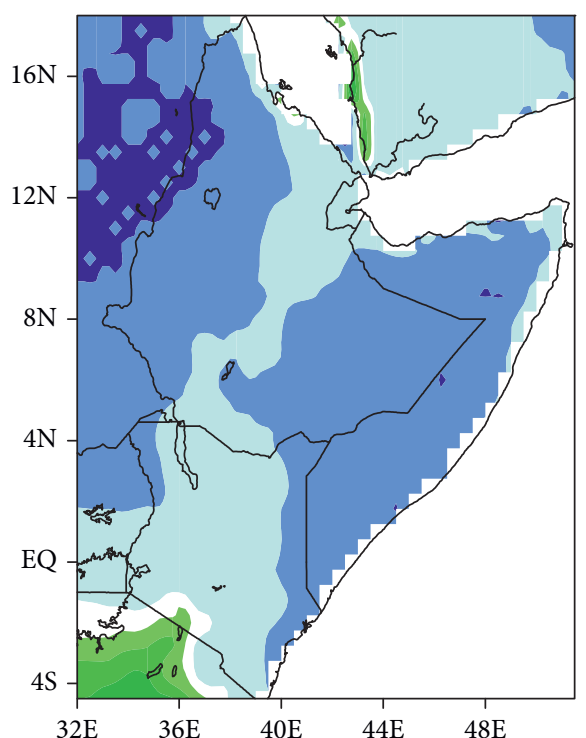

(a)

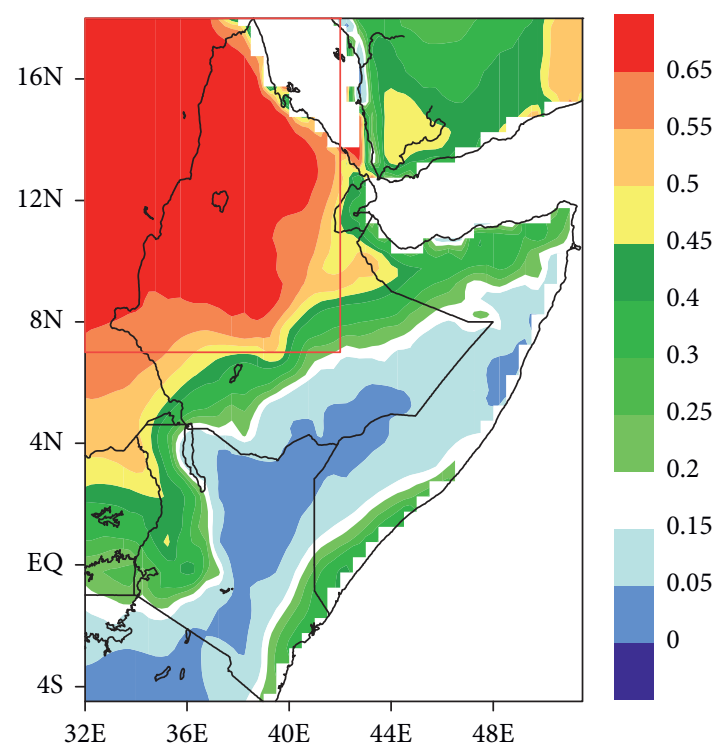

(c)

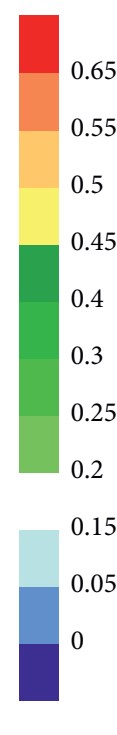

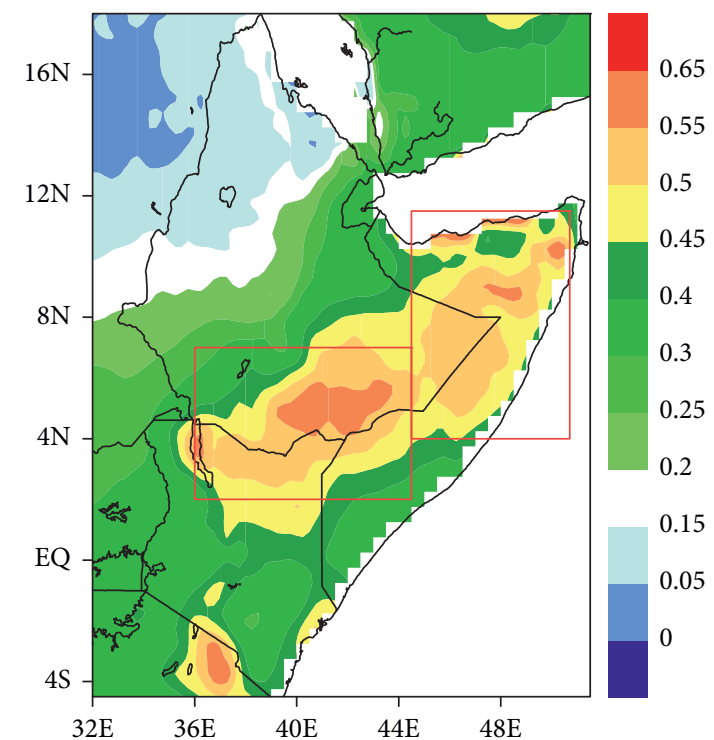

(b)

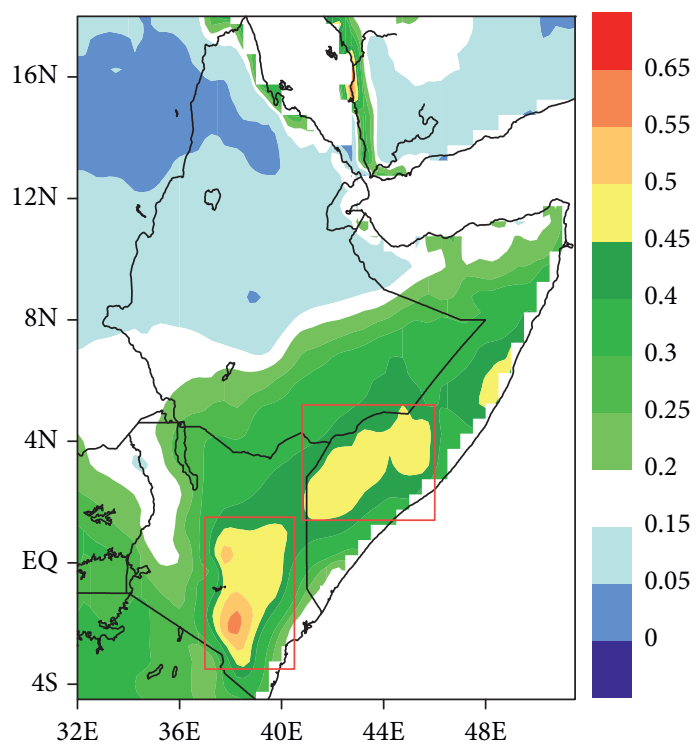

(d)

Figure 2: Seasonal fraction of annual rainfall for the seasons (a) January-February, (b) March-May, (c) June-September, and (d) OctoberDecember. The monthly value obtained from gridded datasets of CRU TS4.01 for the period 1979-2016. Red boxes mark the region we chose for studying, which accounts for greater than $45 \%$ of annual rainfall.

linkage between SST and seasonal rainfall over the area of high fraction of seasonal mean rainfall to annual rainfall. The statistical significance of the results was determined by using a Student's $t$ test.

To demonstrate and extract the dominant modes of spatial homogeneity of seasonal rainfall, an Empirical Orthogonal Function (EOF) method of seasonal rainfall in the GHA is also applied. The EOF method is used to reduce a high-dimensional dataset into fewer dimensions while retaining important information. However, the purpose of EOF in this study is to examine the consistency of study domains between EOF results and high fraction area of seasonal mean rainfall to annual rainfall during the last 38 years.

\section{Results and Discussion}

3.1. Dominant Modes of GHA Seasonal Rainfall. The annual cycle of rainfall averaged over the JJAS region and the OND region is shown in Figure 3. The rainfall over the JJAS region shows a unimodal annual cycle, while the rainfall over the OND region shows a bimodal annual cycle. Comparing with the rainfall over the JJAS region, the rainfall over the OND region has less fraction to annual rainfall, but the rainfall over the OND region has stronger interannual variability (Figure 4).

In order to examine whether the rainfall over the selected regions are spatially homogenous, we apply the EOF analysis. Figure 5 shows the spatial patterns of the first three EOF 


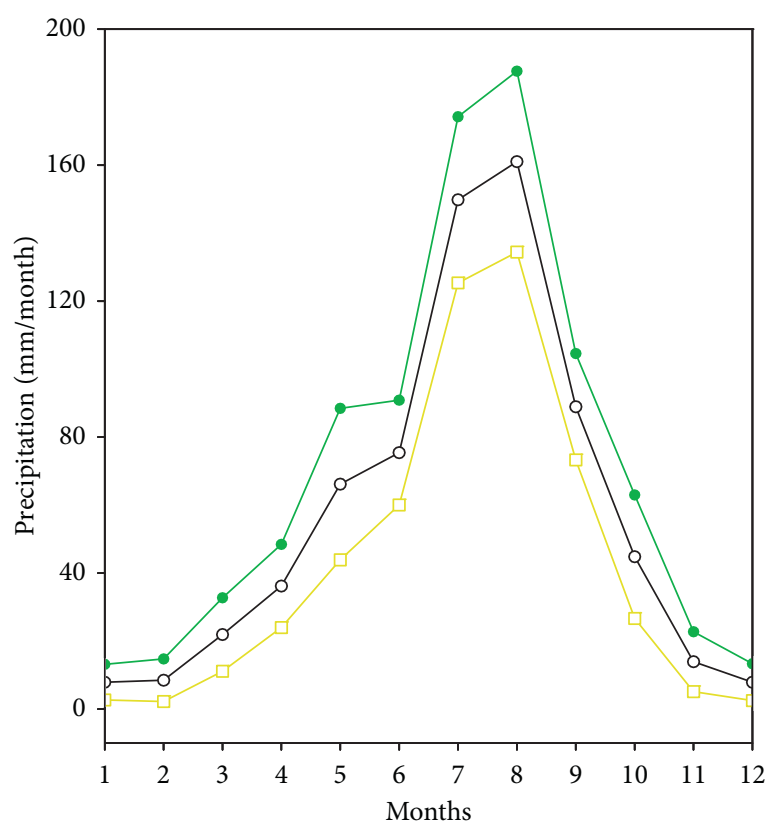

(a)

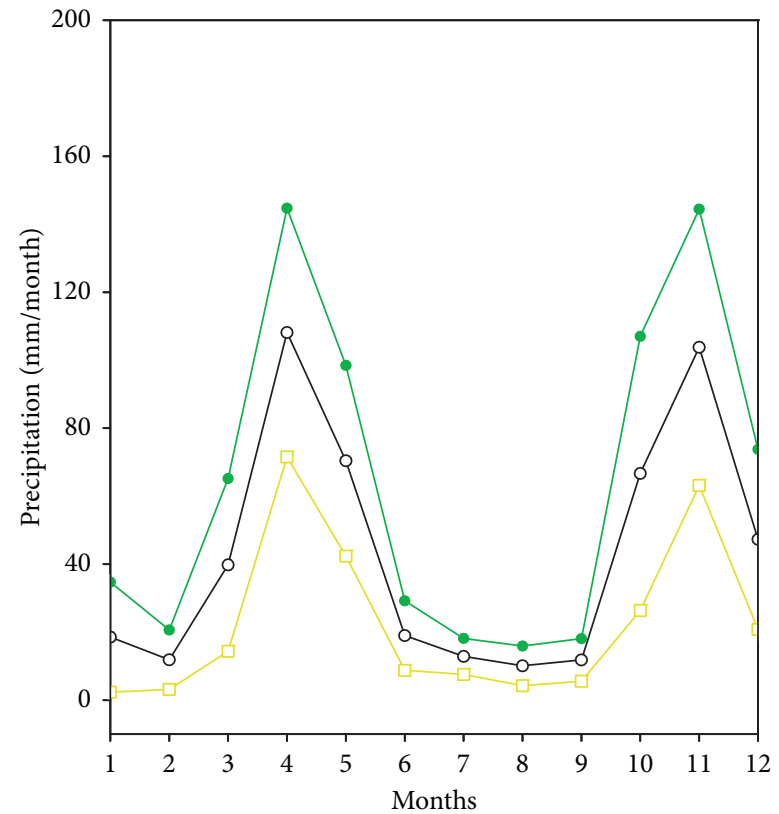

(b)

FIGURe 3: Annual rainfall cycle averaged over (a) the JJAS region and (b) the OND region (red boxes shown in Figure 2(c) and 2(d)). Gray lines are the regions' average, and green and yellow color lines are the \pm 0.1 standard deviation of the interannual variability, respectively.

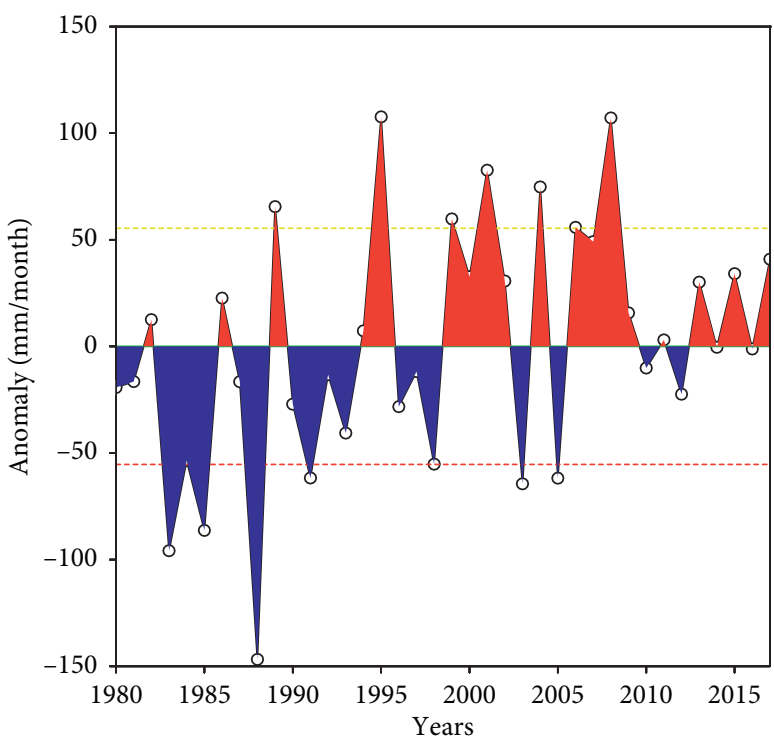

(a)

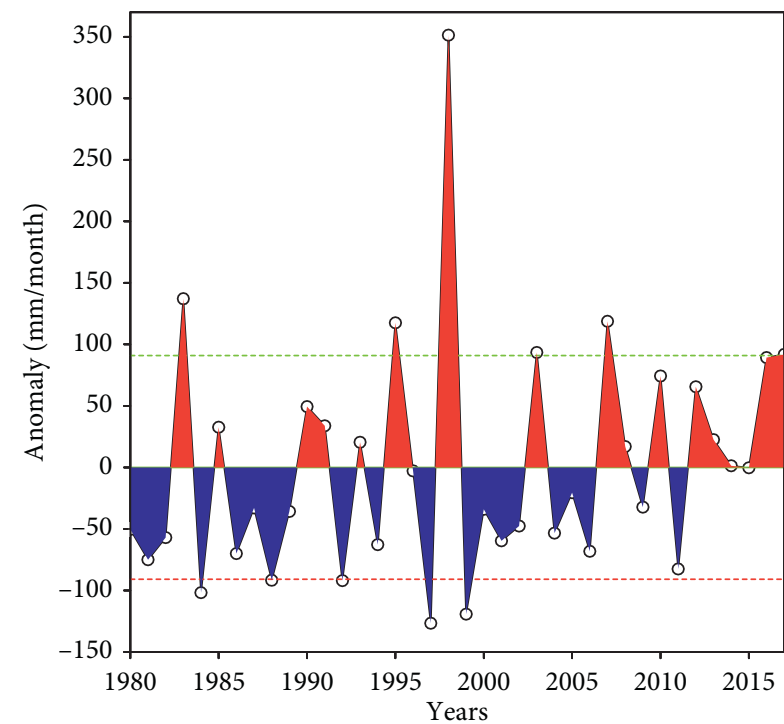

(b)

FIgURE 4: Time series of (a) summer rainfall averaged in the JJAS region and (b) autumn rainfall averaged in the OND region. The horizontal red lines in each panel are the \pm 1 standard deviation.

eigenvalues and principal components (PCs) of summer rainfall over the GHA. The variance of the first and second EOF mode is $31.7 \%$ and $18.7 \%$, respectively. The first mode is characterized by consistent abundant rainfall over the JJAS region, with the center locating over northern Ethiopia. The second mode displays a north/south dipole pattern with negative anomaly in the northwest of Ethiopia and positive anomaly around the border of Sudan, Kenya, and Uganda. The variance of the third EOF mode is $9.8 \%$, which is characterized by the dipole pattern over Ethiopia. The first modes shows spatially homogenous rainfall variability in the selected JJAS region, which indicates that the area-averaged rainfall in the JJAS region can explain more than $31.7 \%$ rainfall variability in this region. It is interesting that the PC1 also shows interdecadal variability with an upward trend. The trend coefficient is 0.04 , which suggest there is some abundant rainfall trend over Ethiopia since 1979 besides the interannual variability. 

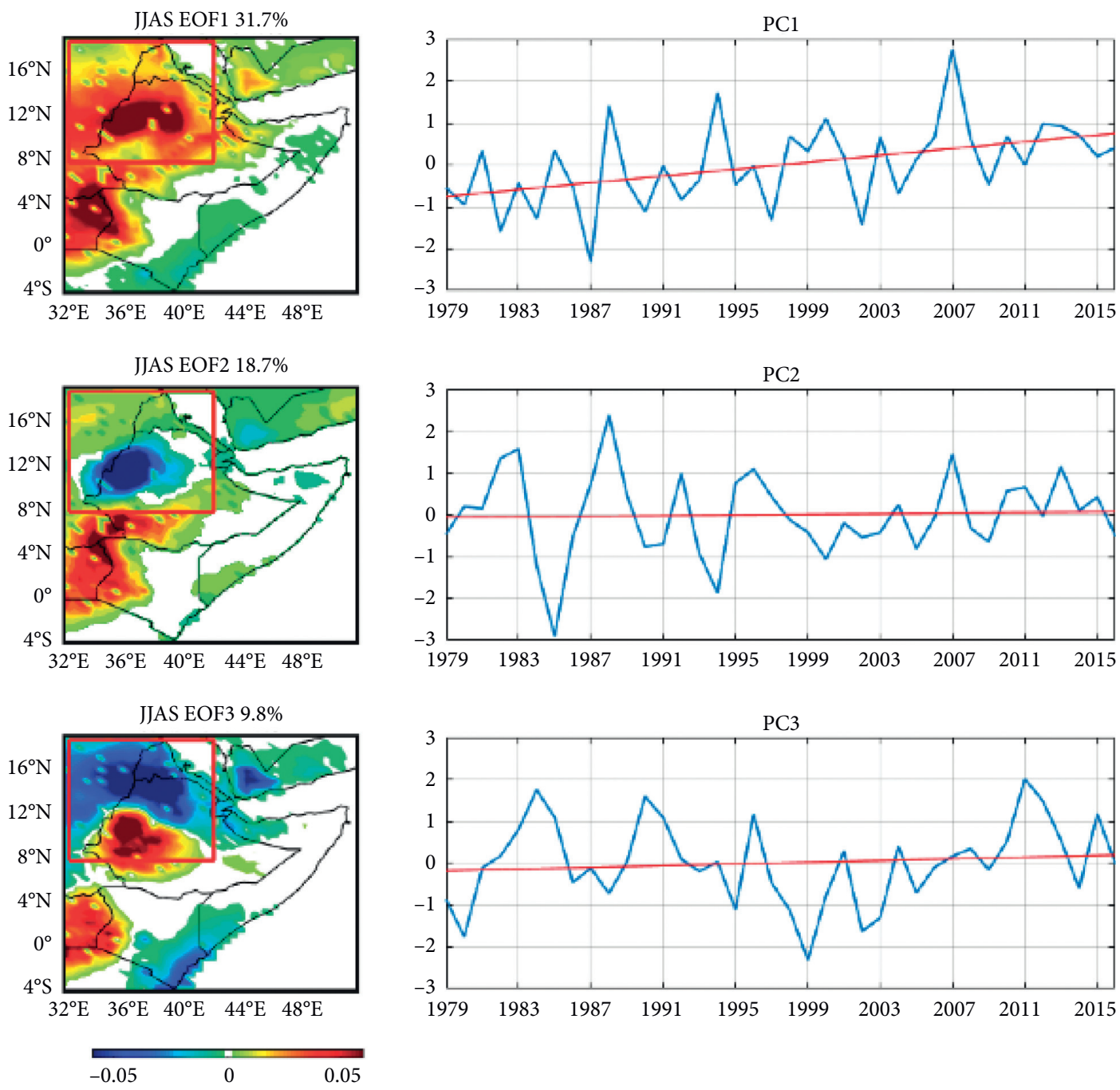

FIGURE 5: Spatial patterns of the first three EOF modes of summer rainfall over the GHA (left panels) and the corresponding principal components: PC1, PC2, and PC3 (right panels), respectively. Red box in left panels is the JJAS region.

Similarly, the first three EOF modes and relevant principal components (PCs) of autumn rainfall over the GHA are shown in Figure 6. The variance of the first EOF mode is $53.1 \%$. The first mode is featured by homogenous positive rainfall anomaly over the whole GHA with the center over southern Kenya, southern Somali and southern Uganda. It is suggested the selected OND region is reasonable. The variance of the second EOF mode is $12.3 \%$. The second mode displays meridional dipole pattern with the positive anomaly in East Ethiopia and negative anomaly in southern Somali. The variance of the third EOF mode is $8.1 \%$, which is characterized by zonal dipole mode over the GHA. During OND season, the years of 1982, 1997, 2002, 2006, and 2015 are wet years as displayed in PC1. Four of them are co-occurrent with pIOD years, as well as the OND regional averaged rainfall (Figure 4(b)). The PC1 for OND rainfall also shows an upward trend with the trend coefficient of 0.03 , which suggest there is abundant rainfall trend over southern Kenya, southern Somali, since 1979 except for the interannual variability.
3.2. Impact of SST. Figure 7 shows the correlation coefficient distribution between monthly global SST and summer rainfall averaged over the JJAS region. The summer rainfall over the JJAS region is significantly correlated with the tropical central-eastern Pacific SST since June. The negative linking SST over tropical Pacific gradually intensifies and extends eastward up to South American coast till September. In other words, JJAS rainfall in Ethiopia and southern Sudan correlates negatively to an El Niño-like SST pattern in the concurrent summer. This result is consistent with that of the previous study. In contrast, the autumn rainfall over the OND region is positively correlated with the El Niño-like SST pattern in Pacific (Figure 8). The OND regional rainfall is not only correlated with SST in Pacific but also positively correlated with equatorial western IO SST and negatively correlated with SST around Maritime continent in the concurrent season. The autumn rainfall averaged over the OND region has a correlation of +0.70 with the OND seasonal mean DMI time series and +0.45 with the OND seasonal mean Niño3.4 time series, which exceeds the 0.05 

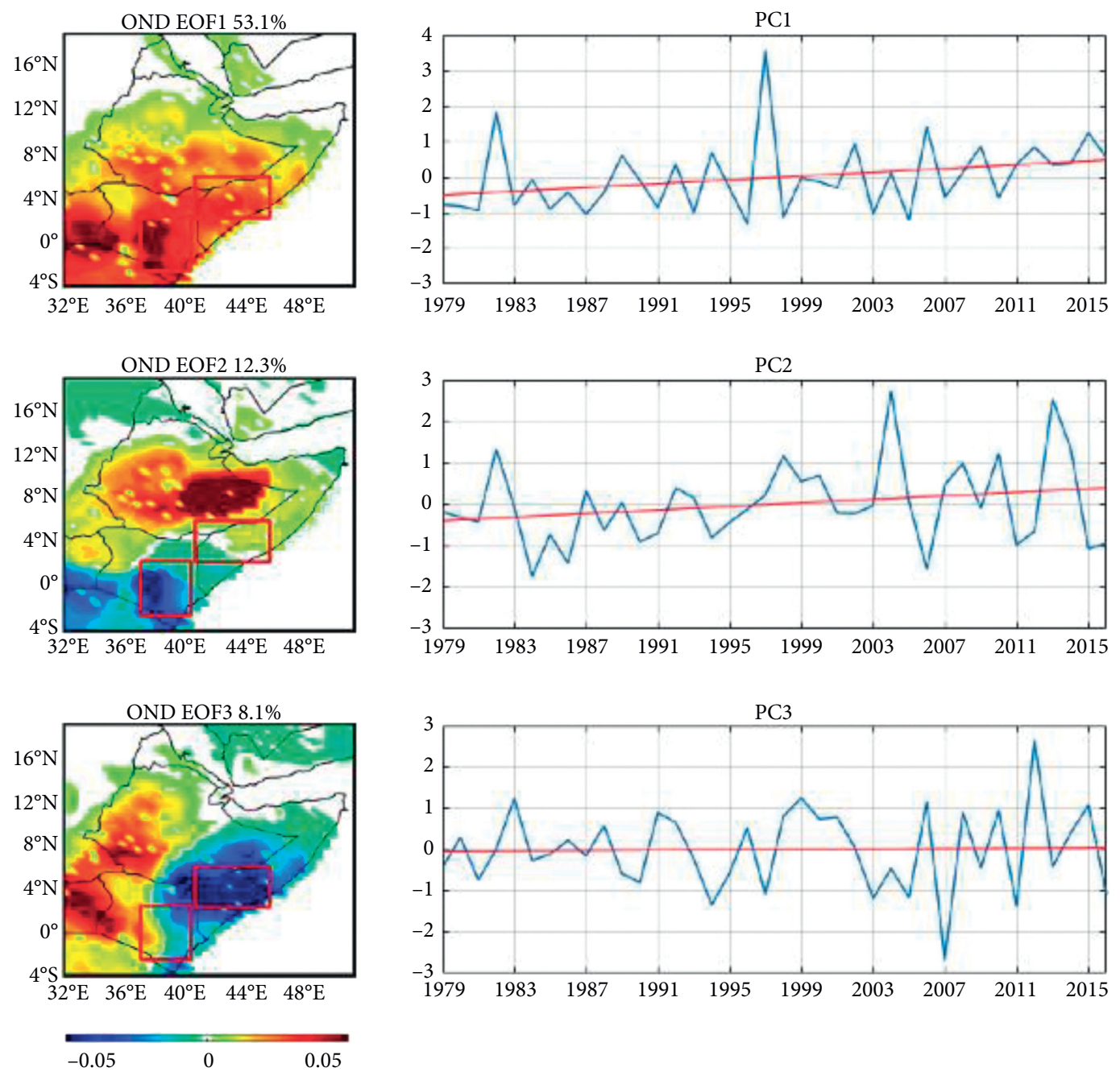

FIGURE 6: Spatial patterns of the first three EOF of autumn rainfall over the GHA (left panels) and the corresponding principal components: PC1, PC2, and PC3 (right panels), respectively. Red boxes in left panels are the OND region.

significance level. In other words, the IOD-like dipole pattern of SST anomalies (SSTA) in the tropical IO plays a dominant role in variability of OND seasonal rainfall in equatorial East Africa. These significant positive correlations observed between autumn rainfall and IOD events are in general agreement with those of other studies [16, 24-27]. Bahaga et al. [16] indicated that a Gill-type response of the atmosphere to a warm SST in western IO induces a low-level westerly anomaly over equatorial Africa, which leads to moisture flux convergence and abundant short rainfall over East Africa. The question is why El Niño-like SSTA in tropical Pacific Ocean will induce below the normal precipitation in Ethiopia during JJAS but above normal precipitation in equatorial East Africa during OND season. Are their mechanisms different? In Section 3.3, it will be examined.

3.3. Different Atmospheric Circulation Responses between JJAS and OND to ENSO. To address the different effects of ENSO on the JJAS and OND rainfall over the two GHA regions, we compare the atmospheric circulation composites between
JJAS and OND rainfall response for ENSO events, IOD events, ENSO alone events, IOD alone events, and ENSO and IOD coexisting events.

Figure 9 shows the climatology of wind and rainfall and composites of rainfall anomalies, wind anomalies at $200 \mathrm{hPa}$ and $850 \mathrm{hPa}$, and related low-level divergence for ENSO events (El Niño years minus La Niña years).

JJAS is a rainy season over northern tropical Africa. The upper-level tropical easterly Jet (TEJ) and ITCZ cover northern tropical Africa and the low level is characterized by convergence in the JJAS region (Figures 9(a), 9(c), and 9(e)). While, during JJAS of warm ENSO years, the upper-level TEJ is weakened by westerly anomalies (Figure 9(b)), the low-level westerly is weakened by easterly anomalies in the northern tropical Africa (Figure 10(a)), and the JJAS region is featured by marginal divergence anomalies (Figure 9(f)). In other words, it is because the Africa monsoon circulation weakening during warm ENSO years induces below normal precipitation in most of the rainy areas (Figure $9(\mathrm{~d})$ ). These results are consistent with those of the previous study $[11,12]$. 


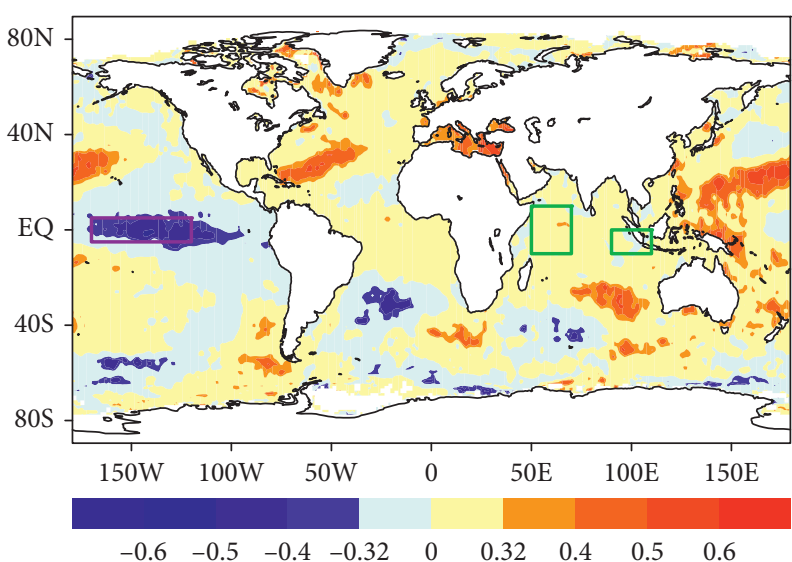

(a)

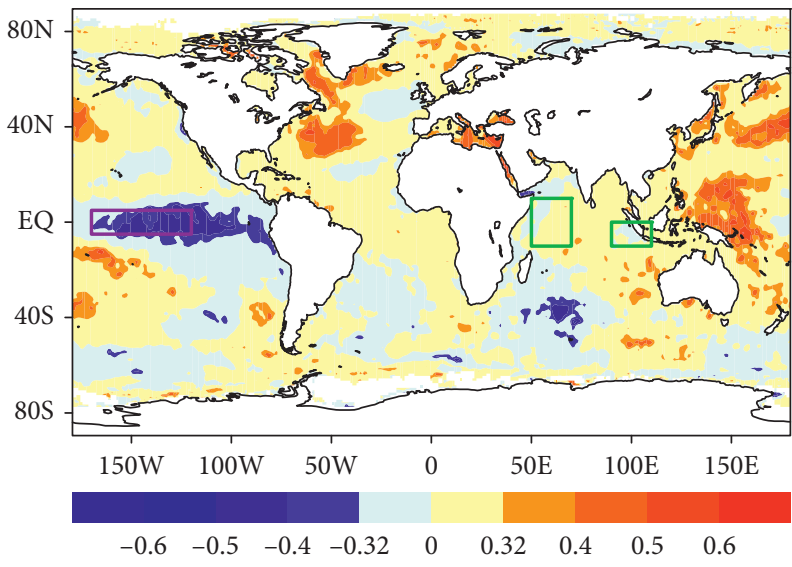

(c)

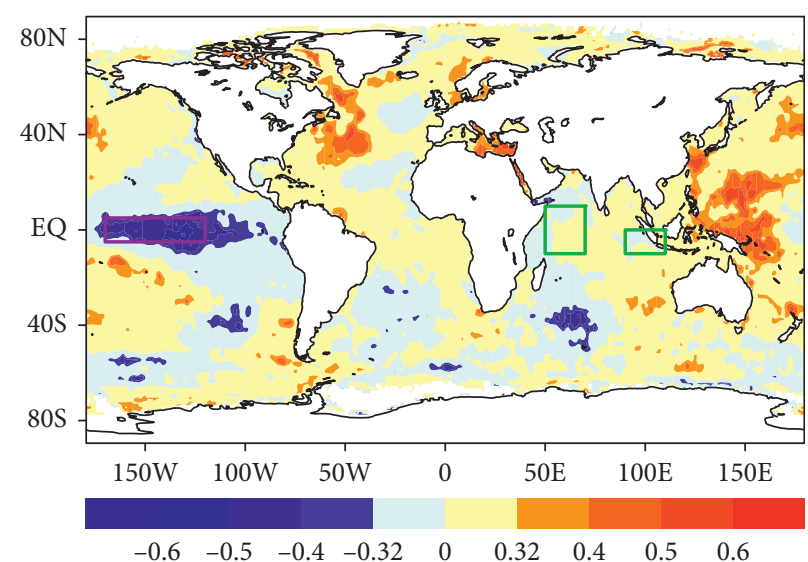

(b)

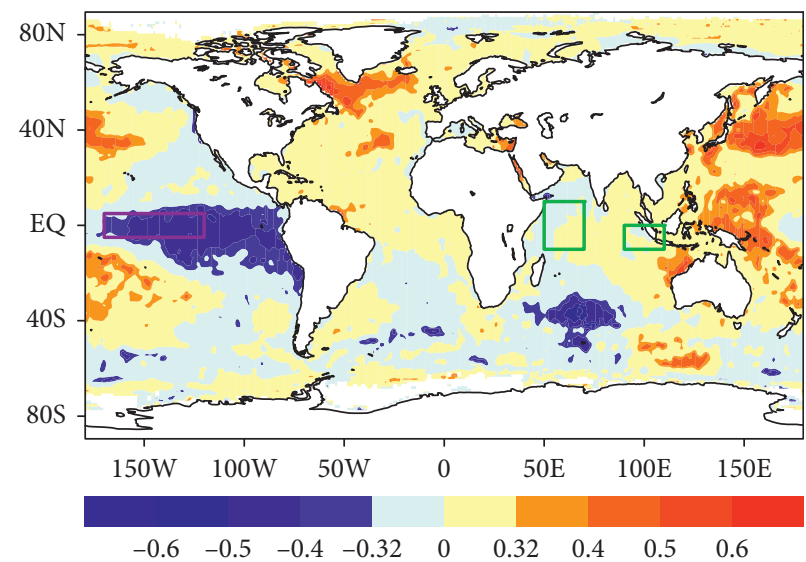

(d)

FIgURE 7: Correlation coefficients between the JJAS region rainfall and global SST in (a) June, (b) July, (c) August, and (d) September. Areas with $95 \%$ confidence level are shown in dark shades. Purple box marks Niño3.4 region and green boxes are western IO and eastern IO, respectively.

For OND climatology, the ITCZ shifts southward and covers southern tropical Africa (Figure 11(c)). Two anticyclones stride over equatorial Africa at the upper level (Figure 11(a)). The OND region locates at east of these two anticyclones and is covered by weak easterly (Figure 11(a)). The low level is characterized by convergence of southeasterly and northeasterly in the OND region (Figure 11(c)). While, during OND of El Niño year, a strong anticyclone anomaly covers the northeastern tropical Africa and a small anticyclonic anomaly covers southern tropical Africa and easterly between two anticyclones is intensified at upper level over the OND region (Figure 11(b)). The low level is featured by easterly anomalies over the tropical IO. The wind anomalies are closely related to the warming SST over western IO (Figure 10(b)), which induces westerly anomalies in equatorial Africa and easterly anomalies over the tropical IO at low-level and then enhances the moisture flux convergence and abundant short rainfall over East Africa, as suggested by Bahaga et al. [16].

Previous studies suggested that the rainfall variability over equatorial East Africa is more closely related to IOD events [16]; the composites of wind anomalies at $200 \mathrm{hPa}$ and
$850 \mathrm{hPa}$ for IOD events are also presented here (Figure 12). In positive IOD years, two anticyclonic anomalies stride at the upper level over tropical Africa and the easterly anomalies are much more enhanced than those in El Niño years (Figure 12(a)). And, low level is characterized by easterly anomalies over equatorial IO and enhanced convergence over equatorial Africa with northerly and anticyclonic anomalies in northern tropical Africa and southerly in southern tropical Africa (Figures 12(b), 12(c), and 10(c)).

Some of IOD events are related to ENSO events. Figure 13 presents the composites of rainfall anomalies, wind anomalies at $200 \mathrm{hPa}$ and $850 \mathrm{hPa}$ for ENSO alone events, IOD alone events, and ENSO and IOD coexisting events, respectively. As shown in Figure 13, abundant OND rainfall appears over equatorial Africa both in warm IOD alone years and El Niño and pIOD coexisting years. But, the autumn rainfall in the OND region is far greater in El Niño and PIOD coexisting years than that in positive IOD alone years, which suggests that ENSO has a significant impact on the autumn rainfall over equatorial East Africa. On the other hand, the autumn rainfall over the OND region has no evident anomalies in ENSO alone years, which suggests that IOD is 


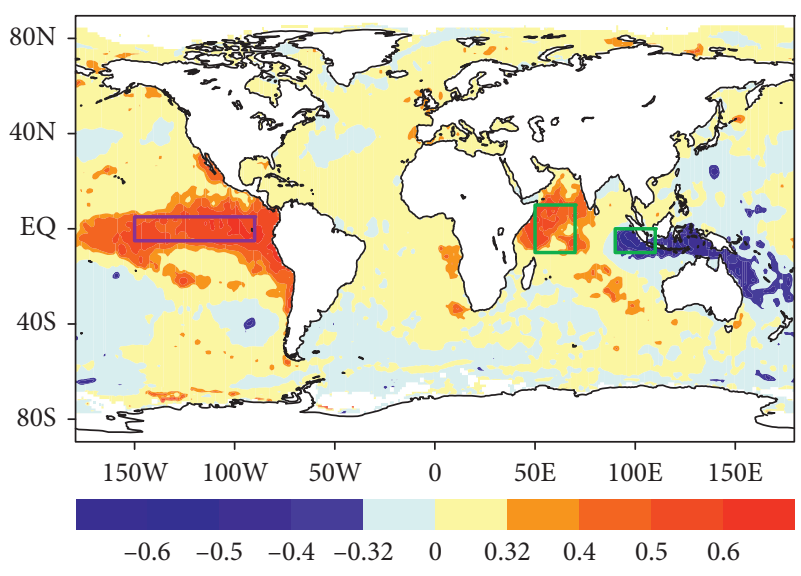

(a)

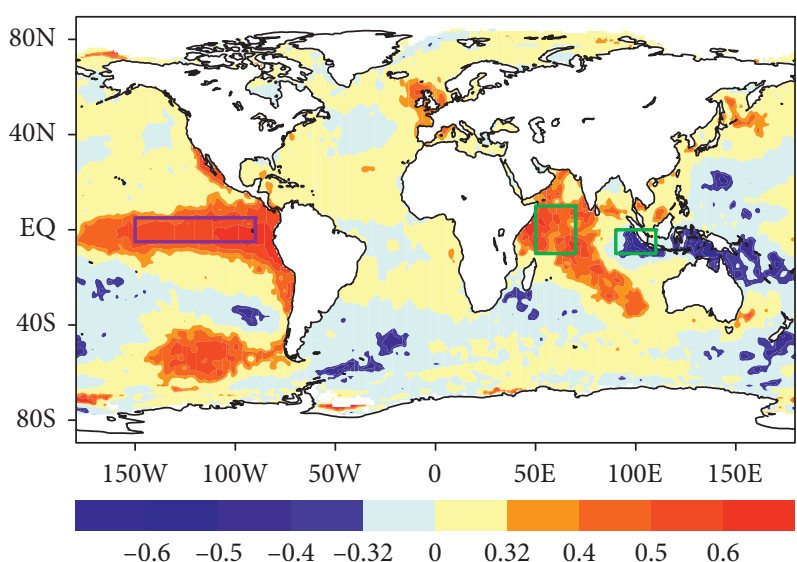

(b)

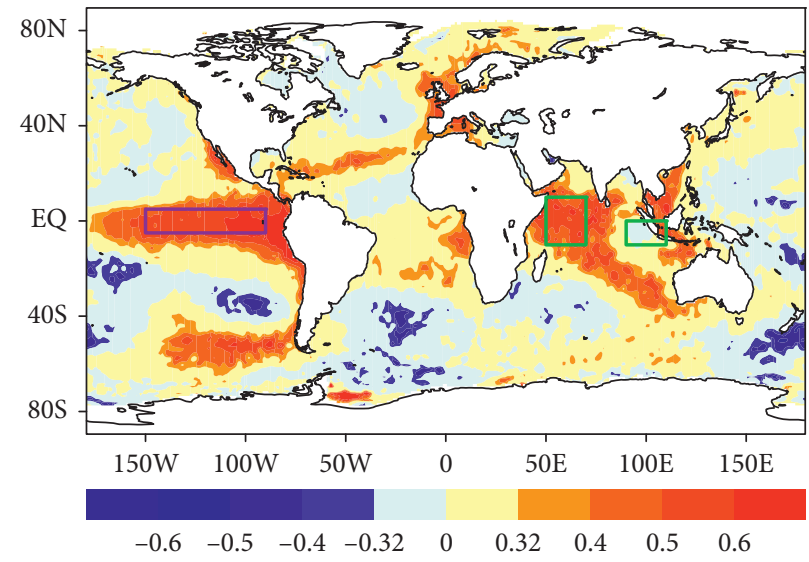

(c)

FIGURE 8: Correlation coefficients between the OND region rainfall and global SST in (a) October, (b) November, and (c) December. Areas with $95 \%$ confidence level are shown in dark shades. Purple box marks Niño3.4 region and green boxes are western IO and eastern IO, respectively.

pivotal in having ENSO in effect in autumn rainfall over the OND region. The circulation has the similar characteristic. The low-level easterly anomalies in equatorial IO are far greater in El Niño and pIOD coexisting events than those in other two events.

The opposite response of JJAS rainfall and OND rainfall in East Africa to El Niño-like SST can also be observed in the field of OLR (Figures 14 and 15). Negative (positive) OLR anomalies indicate enhanced (suppressed) convection. During JJAS of El Niño alone years, the zonal wave one pattern of OLR anomalies are observed along the equator, with positive OLR anomalies extending from tropical Atlantic to tropical Africa and till the Maritime Continent; negative OLR anomaly covers the equatorial Pacific (Figure 14(a)). The zonal wave one pattern can also be observed in summer of ENSO and IOD coexisting years (Figure 14(c)) with much weak positive OLR anomalies in tropical Africa and much intense positive OLR anomalies over the Maritime Continent, which suggests that the IOD events offsets some effect of ENSO on the summer rainfall over the GHA. In positive IOD alone years, the negative OLR anomalies are observed over western IO (Figure 14(b)).
During OND of El Niño and pIOD years, the zonal wave two pattern of OLR anomalies is observed along the equator (Figure 15(c)). One negative OLR anomaly extends from tropical East Africa to tropical western IO. Another region of negative OLR anomalies covering is tropical central-eastern Pacific. Two positive OLR anomalies are located in the Maritime Continent and the tropical western Atlantic, respectively. In ENSO alone years, the autumn anomalies of OLR are not evident in tropical Africa and the Indian Ocean (Figure 15(a)), but they can be observed in autumn of IOD alone years (Figure 15(b)), which also suggest that IOD is pivotal in having ENSO in effect in autumn rainfall over the OND region.

The location of the low (high) sea level pressure (SLP) matches with the enhanced (suppressed) convection in the tropics (Figures 14 and 15). During JJAS of El Niño alone years (Figure 14(a)), above-normal SLP extends from tropical Atlantic to Maritime continent and below-normal SLP extends cross tropical central-eastern Pacific. It exhibits a tropical zonal wave one pattern. While during OND of El Niño and positive IOD years (Figure 15(c)), East Africa is overlying with marginal negative anomalies of SLP and the central-eastern Pacific is overlying with negative anomalies 


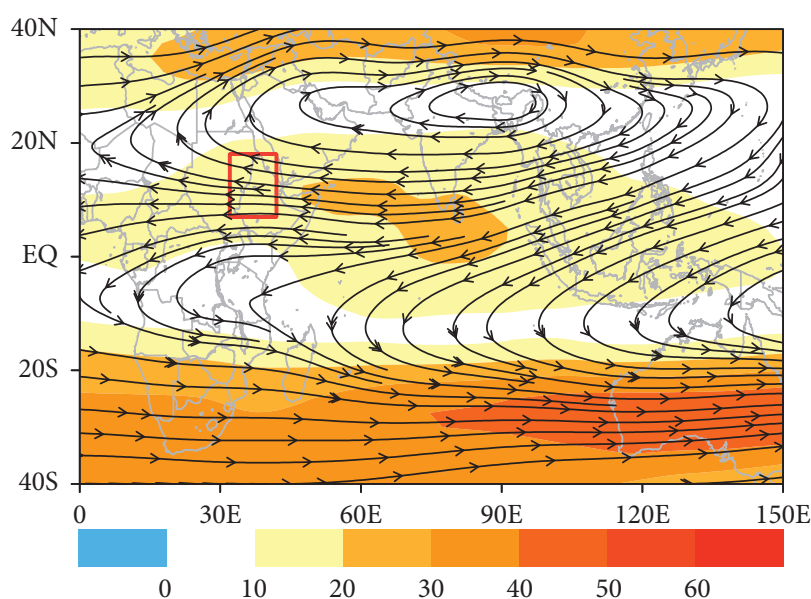

(a)

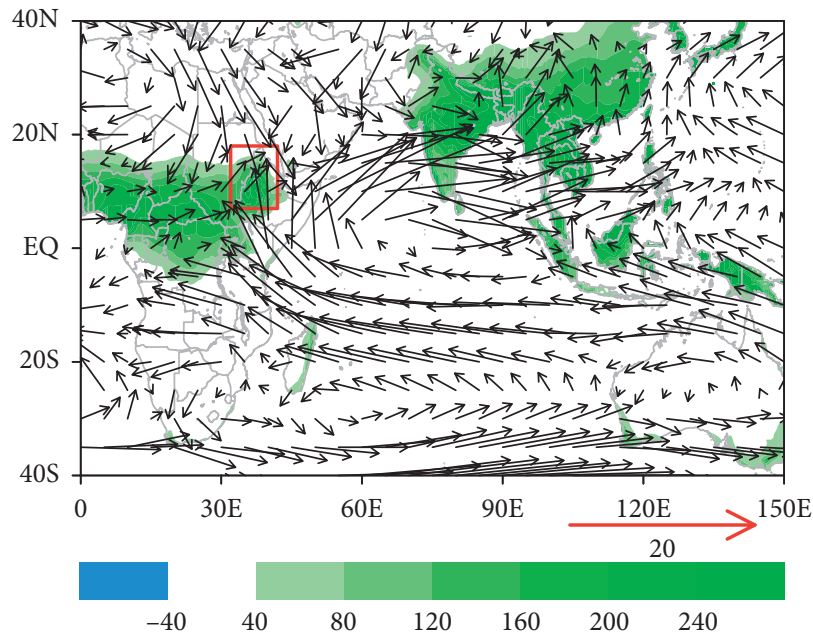

(c)

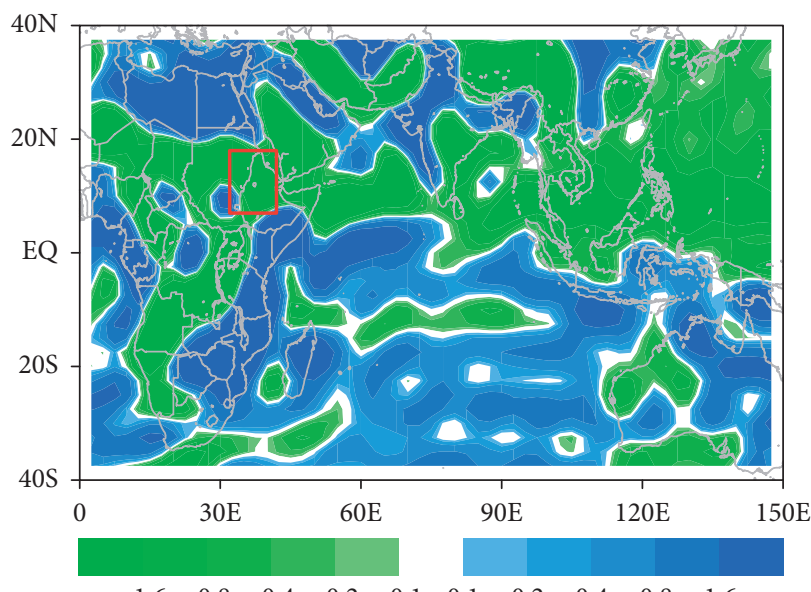

$\begin{array}{llllllllll}-1.6 & -0.8 & -0.4 & -0.2 & -0.1 & 0.1 & 0.2 & 0.4 & 0.8 & 1.6\end{array}$

(e)

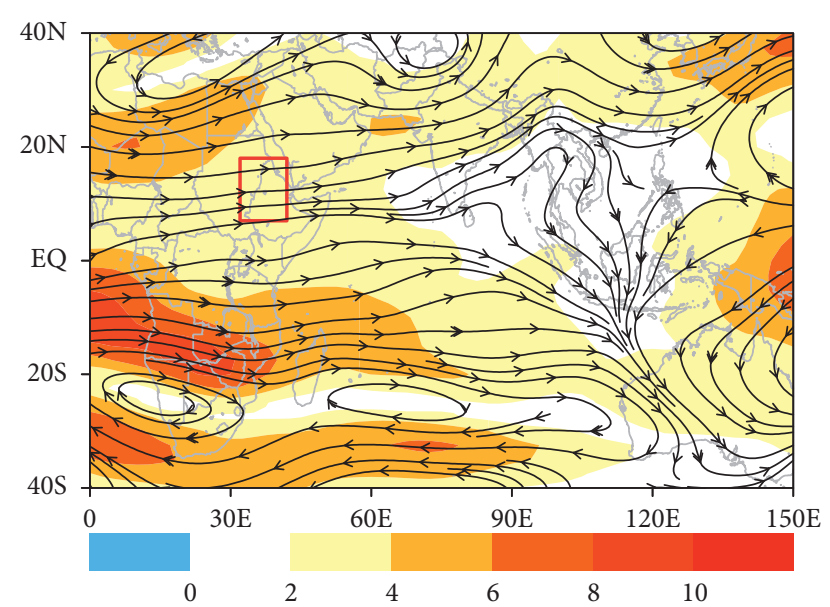

(b)

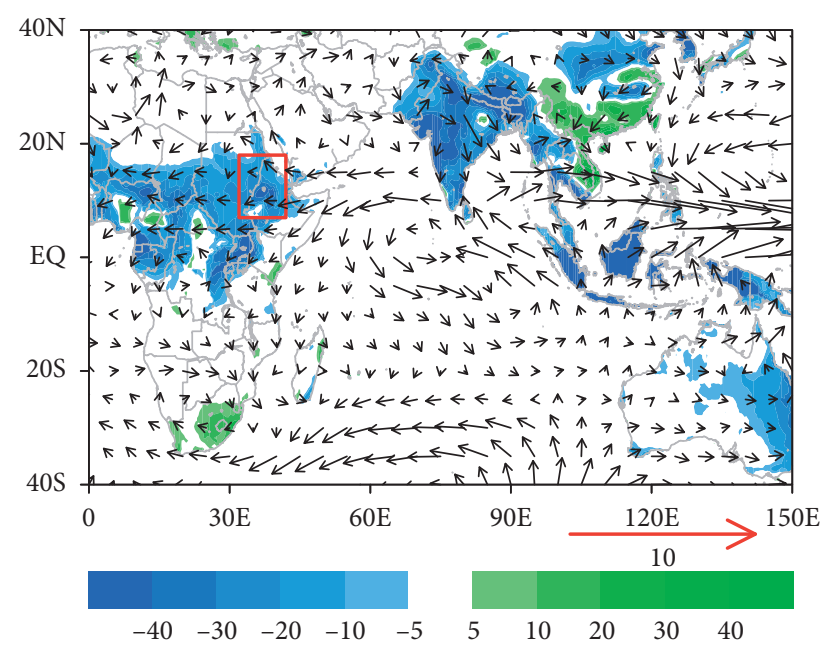

(d)

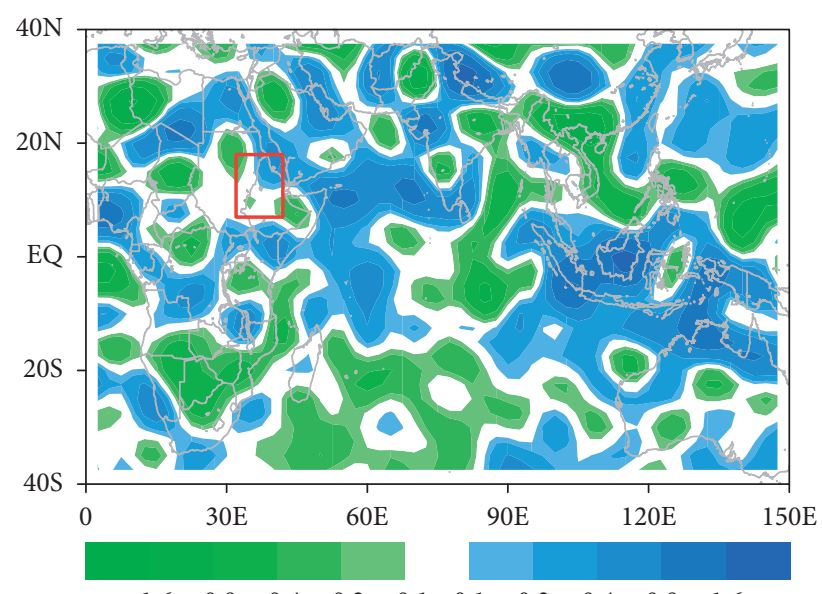

$\begin{array}{llllllllll}-1.6 & -0.8 & -0.4 & -0.2 & -0.1 & 0.1 & 0.2 & 0.4 & 0.8 & 1.6\end{array}$

(f)

Figure 9: Climatological (a) 200-hPa wind (streamline), (c) 850-hPa wind (vector in $\mathrm{m} / \mathrm{s}$ ) and rainfall (shaded in $\mathrm{mm} \mathrm{month}^{-1}$ ), and (e) 850 $\mathrm{hPa}$ divergence (shaded in $10 \mathrm{e}^{-1} \mathrm{~s}^{-1}$ ) in JJAS. The difference of (b) 200-hPa wind (streamline), (d) 850-hPa wind (vector in m $\mathrm{s}^{-1}$ ), rainfall (shaded in $\mathrm{mm} / \mathrm{month}$ ), and (f) 850 -hPa divergence (shaded in $10 \mathrm{e} 6 \mathrm{~s}^{-1}$ ) in JJAS between El Niño and La Niña years. The magnitudes of wind are shaded in (a) and (b). The red box marked in each panel represents the JJAS region. 


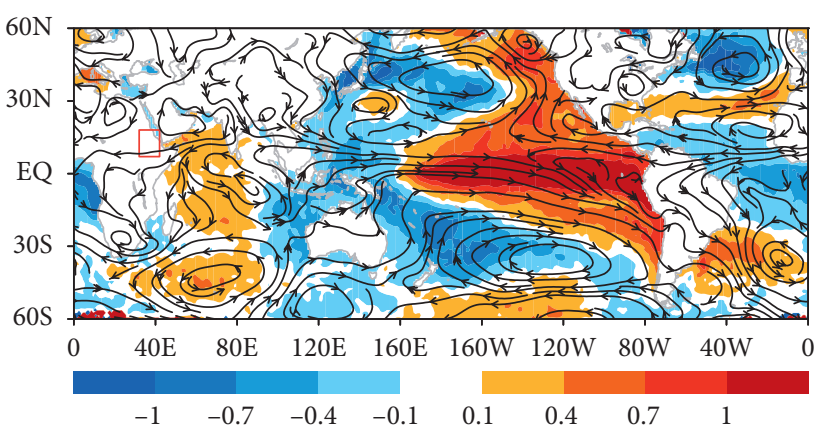

(a)

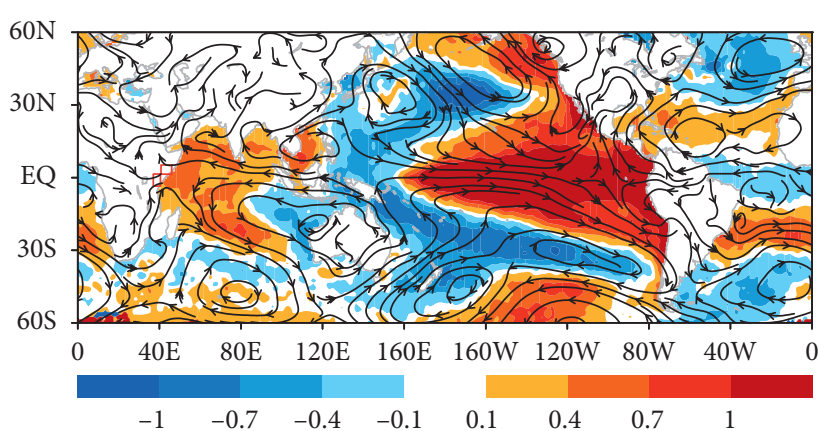

(b)

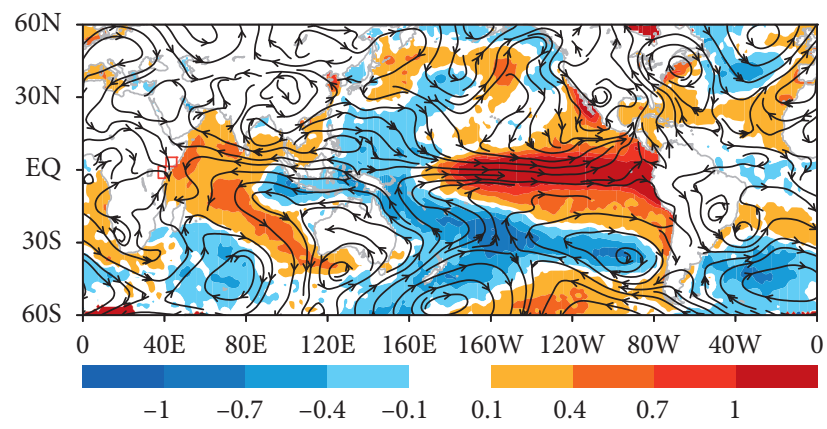

(c)

FIgURE 10: The difference of SST (shaded in ${ }^{\circ} \mathrm{C}$ ) and 850-hPa wind (streamline) in (a) JJAS between El Niño years and La Niña years, (b) OND between El Niño years and La Niña years, and (c) OND between pIOD years and nIOD years.

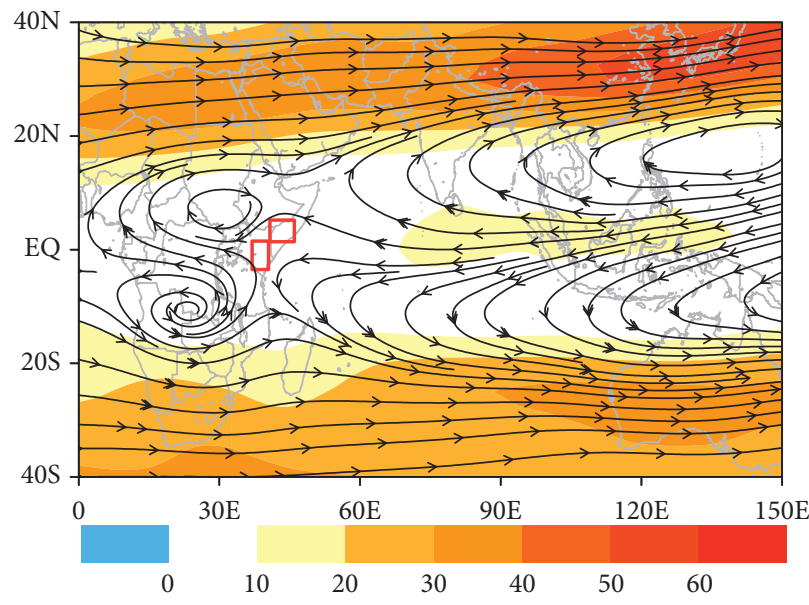

(a)

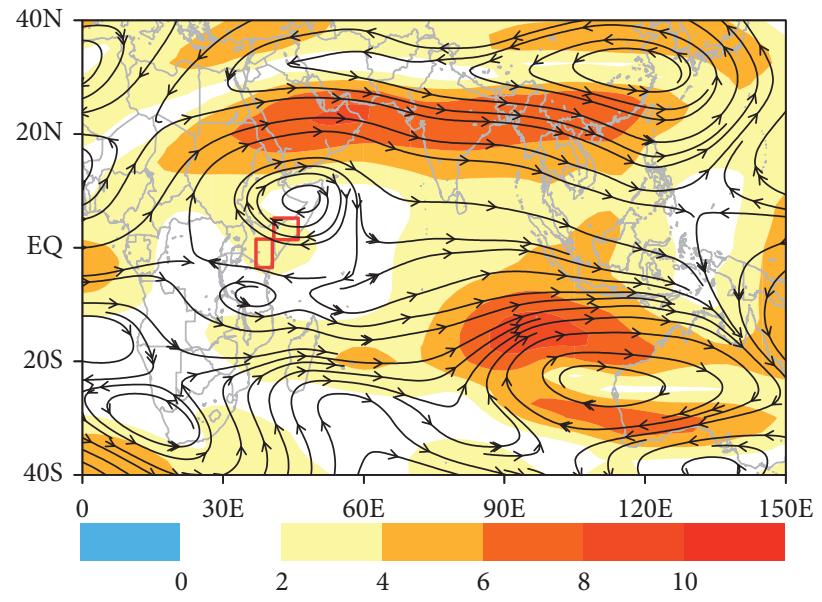

(b)

Figure 11: Continued. 


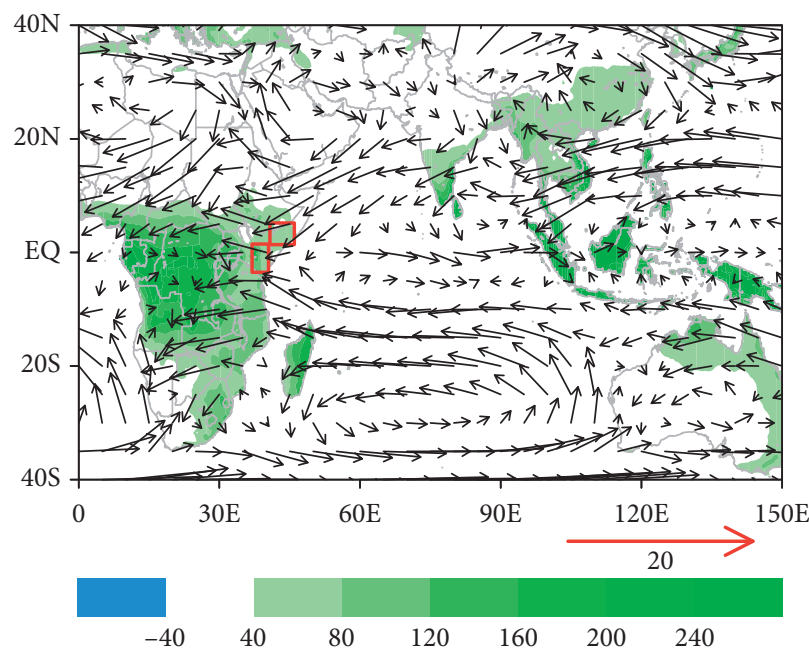

(c)

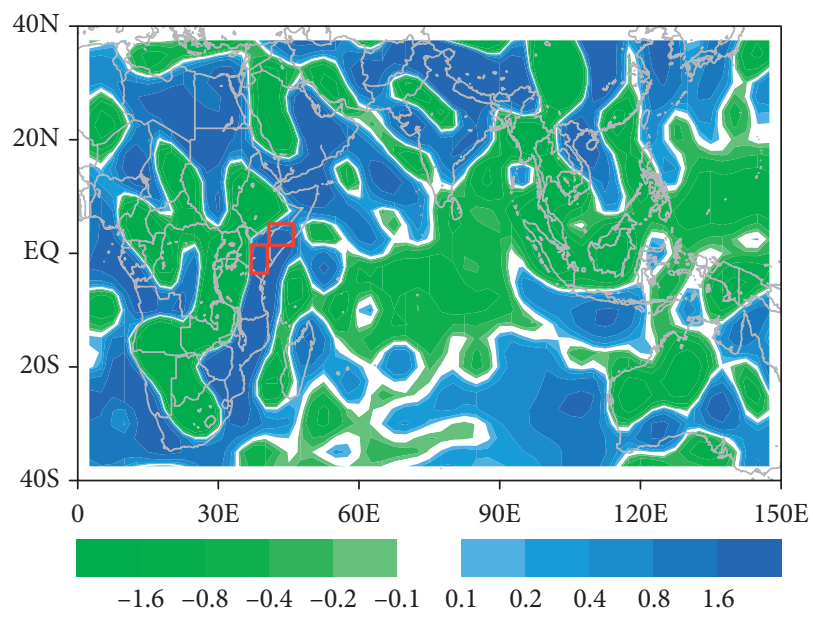

(e)

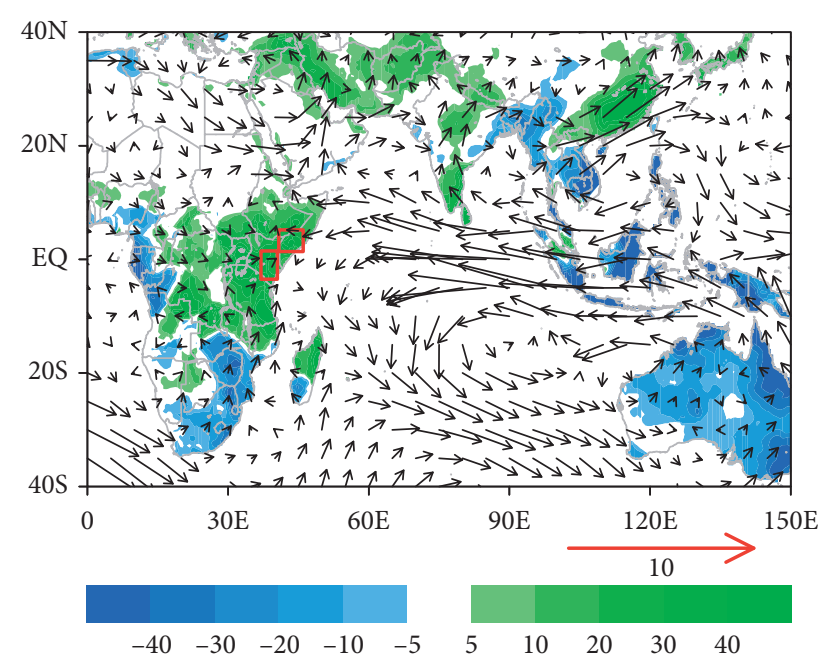

(d)

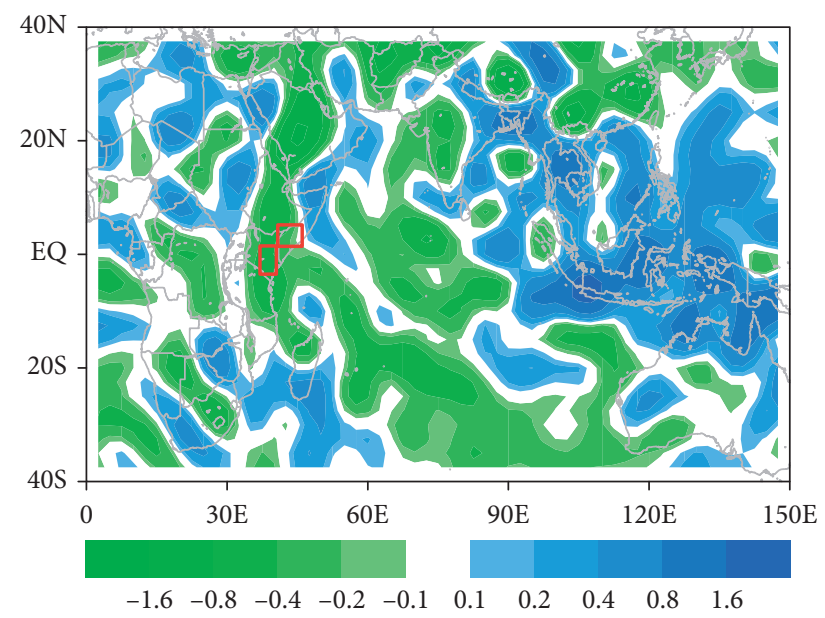

(f)

FIgURe 11: Same as Figure 9, but for OND season. (a) OND 200- hpa wind clim. (b) OND 200- hpa wind anomaly. (c) OND RF and 850-hpa wind clim. (d) OND RF and 850-hpa wind anomaly. (e) OND low-level divergence clim. (f) OND low-level divergence anomaly

of SLP. The above normal SLP extends from tropical Atlantic to tropical western Africa as well as Maritime Continent. It exhibits a tropical zonal wave two pattern.

Though the composites of SST anomalies patterns in JJAS and OND of El Niño year are similar (Figure 10), response of JJAS rainfall and OND rainfall in East Africa to El Niño-like SST is opposite. It is because the warming SST over western IO is fully grown in autumn in some El Niño years, induces low-level convergence between easterly anomaly in tropical IO and westerly anomaly in tropical Africa, and enhances the convection over equatorial East Africa (Figure 10(b)).

\section{Summary and Discussion}

In this study, we compare the interannual rainfall variation of JJAS and OND over the GHA and explore their different possible causes by using the datasets for the period 1979-2016. Based on the spatial distribution of high seasonal fraction to annual rainfall, we identify two rainfall regions over GHA: JJAS region and OND region. The JJAS region is in northern GHA and has a unimodal annual cycle of rainfall. The OND region is in southern GHA and has a bimodal annual cycle of rainfall. The results show that Niño3.4 SST significantly affects the variability of JJAS rainfall and OND rainfall over East Africa. Summer rainfall in the JJAS region is negatively correlated with the El Niñolike SST pattern, whereas autumn rainfall is positively correlated with the El Niño-like SST pattern. We further examine and compare the mechanisms between them. For JJAS rainfall variability, the Africa monsoon circulation is weakened with the weakened upper level TEJ and the weakened low-level southwesterly over the JJAS region, which induces below normal precipitation over most of rainy area including the JJAS region. IOD is pivotal in effect in autumn rainfall over East Africa. These results are consistent with those of the previous studies. Though the autumn rainfall anomalies are not evident in ENSO alone 


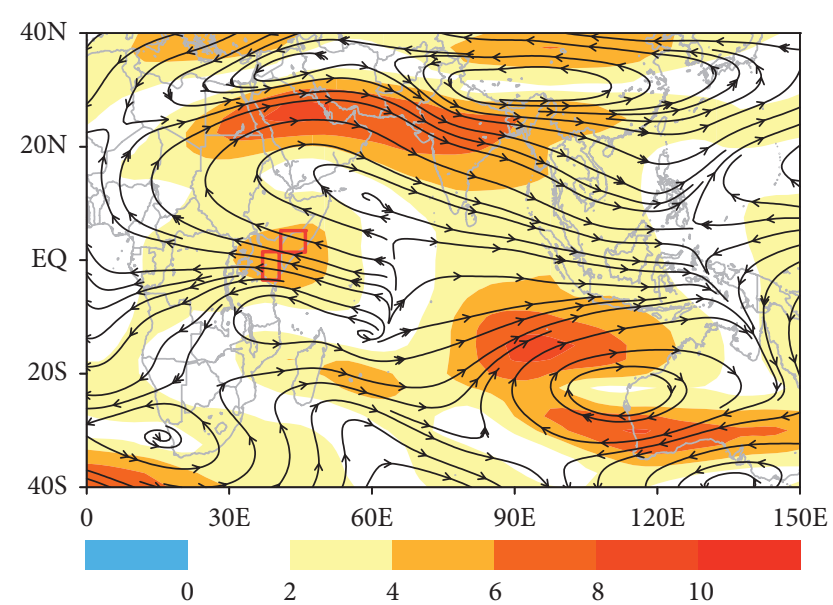

(a)

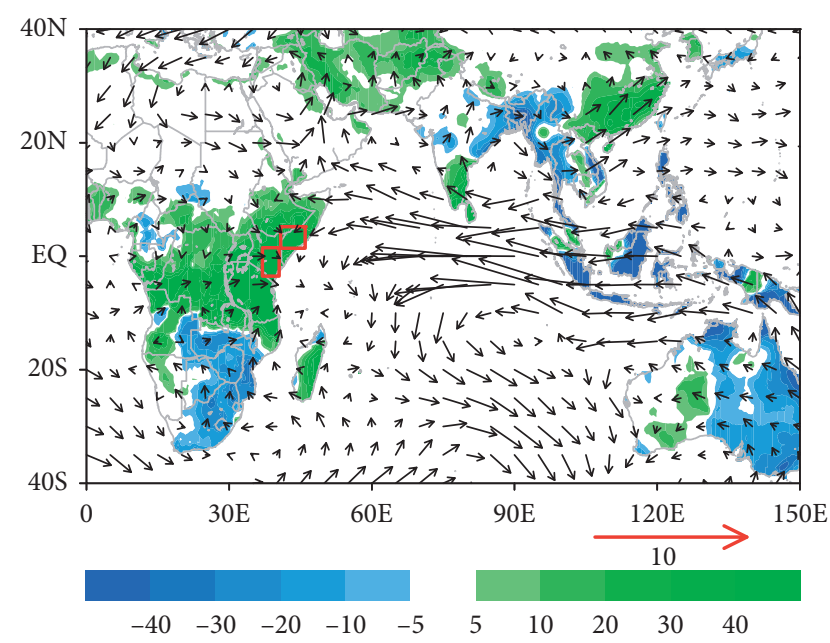

(b)

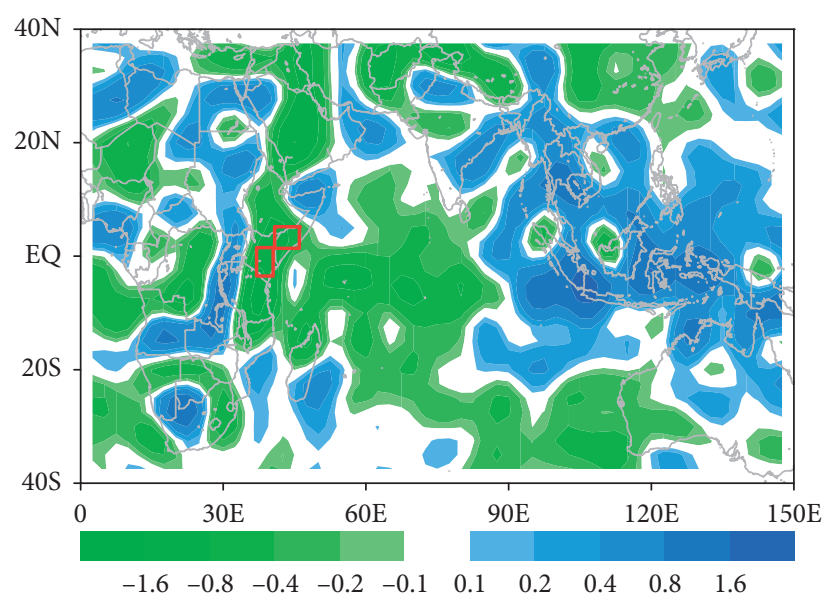

(c)

Figure 12: The difference of (a) 200-hPa wind (streamline), (b) 850-hPa wind (vector in $\mathrm{m} \mathrm{s}^{-1}$ ) and rainfall (shaded in $\mathrm{mm} \mathrm{month}^{-1}$ ), and (c) 850 - $\mathrm{hPa}$ divergence ( shaded in $10 \mathrm{e}^{-1} \mathrm{~s}^{-1}$ ) in OND between positive IOD years and negative IOD years. The magnitudes of wind are shaded in (a). The red boxes marked in each panel represent the OND region.

years, rainfall anomalies are more pronounced when IOD events are concurrent with ENSO events. The intensified upper-level TEJ and enhanced low-level moisture flux convergence by easterly anomalies over tropical IO and westerly anomalies over tropical Africa triggered by the positive SST anomalies over western IO are favorable for abundant rainfall over East Africa. The warming SST fully grown in western IO during El Niño autumn is the reason for the opposite response of summer rainfall and autumn rainfall in East Africa to El Nino-like SST in Pacific. In one word, IOD is pivotal in having ENSO in effect in autumn rainfall over the East Africa, and ENSO has significant impact on autumn rainfall over East Africa by means of IOD (Figure 16).

IOD events are closely related to ENSO events. As proposed by Li et al. [28], El Niño may induce positive IOD by the change of the walker circulation. The suppressed convection in Maritime Continent may induce anomalous easterlies at equatorial IO, which favors a warm SSTA in western IO as a result of the negative wind stress curl, thereby depressing of thermocline. Another process which favors a warm SSTA in western IO is the weakening of the Indian summer monsoon [28]. Prasad and McClean [29] supported the view that the warming in western IO is primarily a response to local wind anomalies. The warm SST in western IO favors deep convective clouds in western IO, which is mainly responsible for precipitation in equatorial East Africa in autumn.

But not every IOD events are companied by ENSO. Zhang et al. [30] documented that the relationship between the eastern Pacific El Niño and the IOD depends on the strength of El Niño, whereas for the central Pacific El Niño, its horizontal location is more important to exciting an IOD. Fan et al. [31] suggested that strong IOD development is 


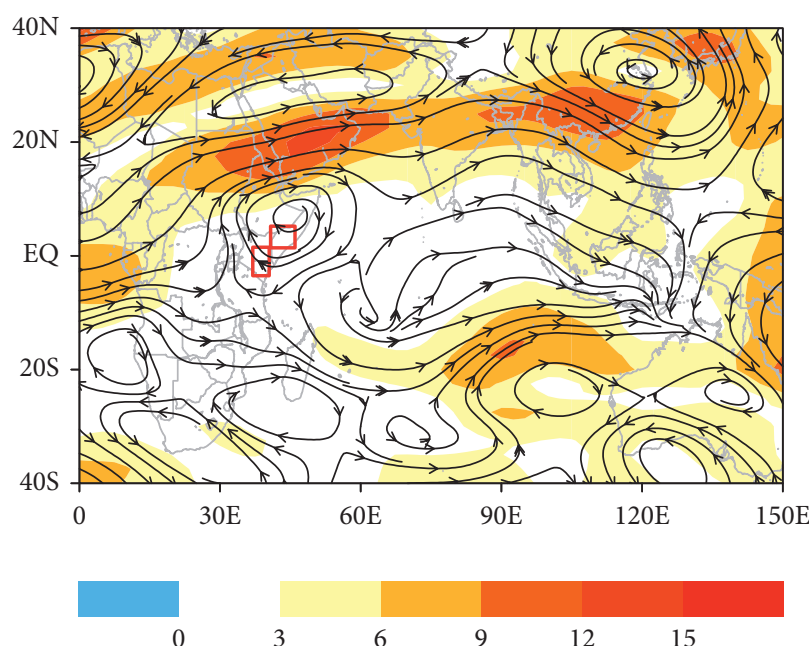

(a)
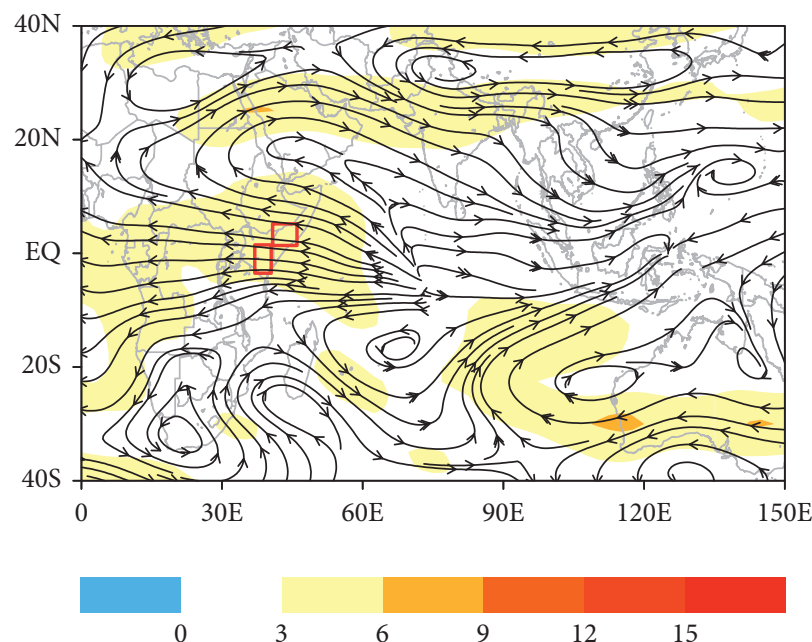

(c)
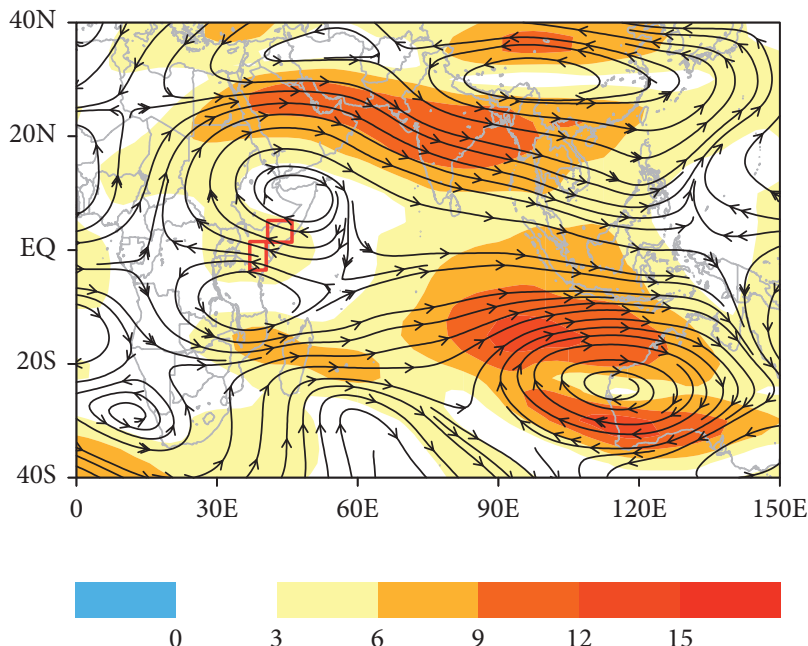

(e)

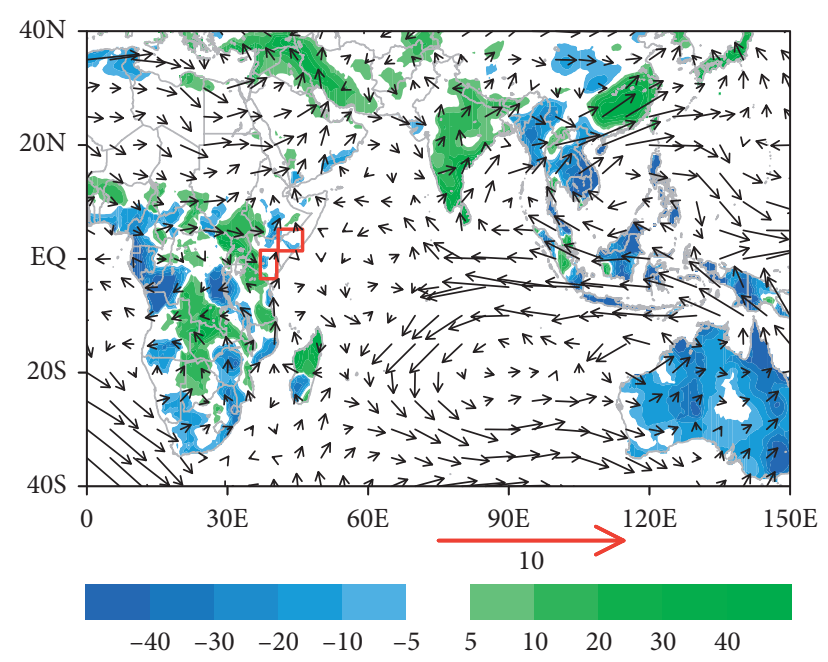

(b)

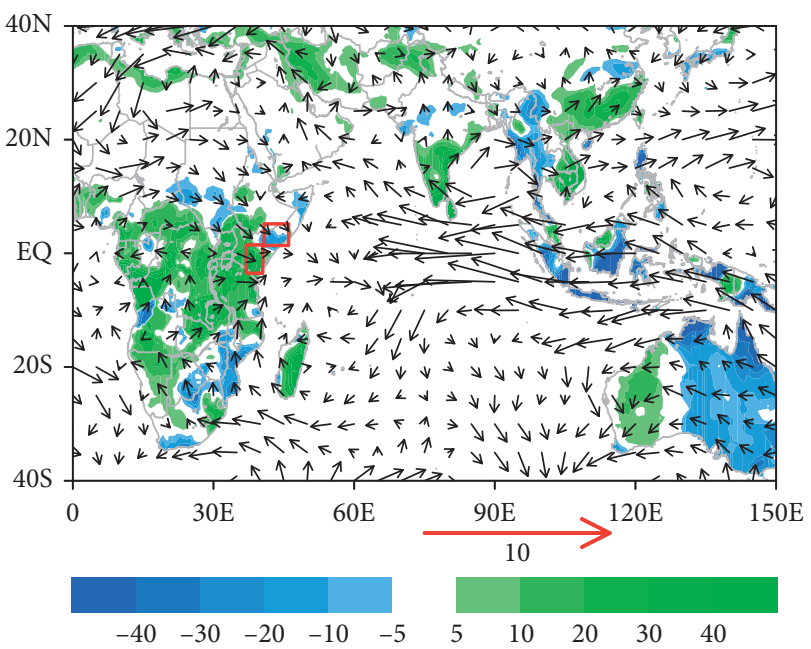

(d)

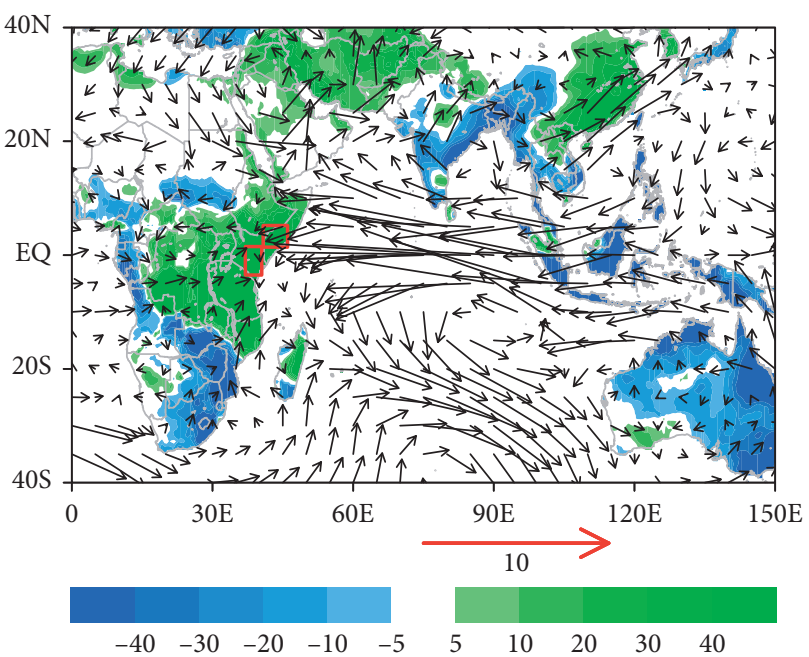

(f)

Figure 13: The difference of 200-hPa wind (streamline; left column), 850-hPa wind (vector in $\mathrm{m} \mathrm{s}^{-1}$ ), and rainfall (shaded in mm month ${ }^{-1}$ ) (right column) in OND between El Niño alone and La Niña alone years (a, d), between pIOD alone years and nIOD alone years (b, e), and between El Niño and pIOD coexisting and La Niña and nIOD coexisting years $(c, f)$. The magnitudes of wind are shaded in $(a, b$, and $c)$. The red boxes marked in each panel represent the OND region. 


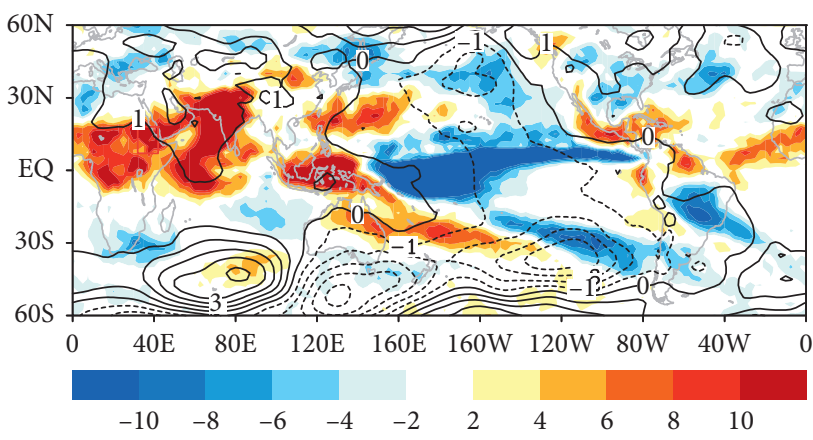

(a)

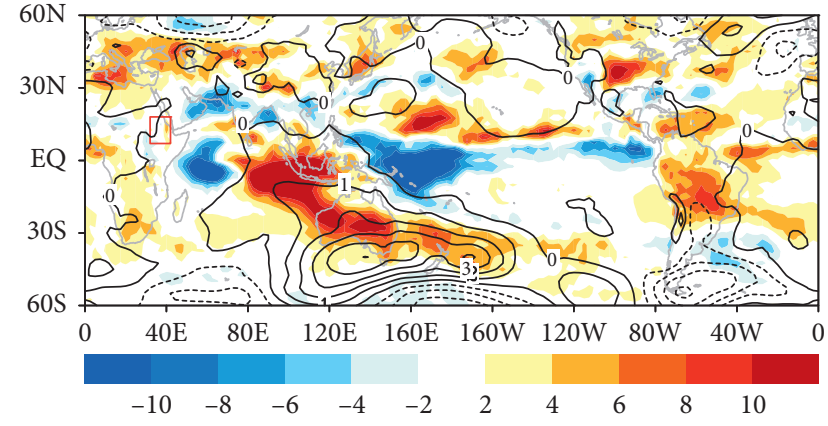

(b)

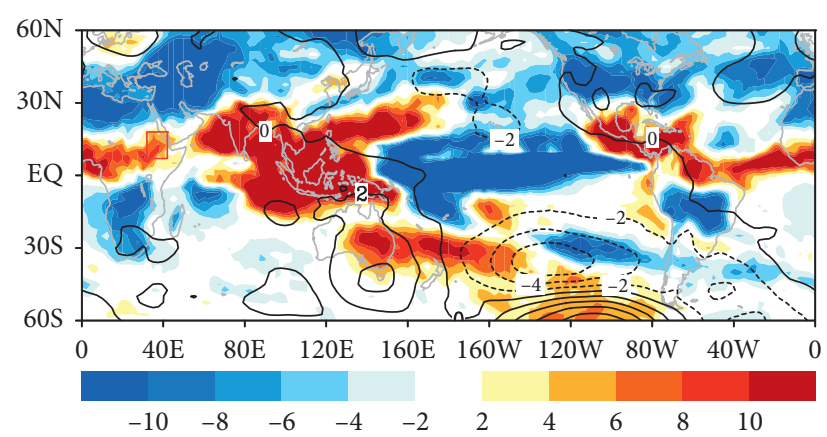

(c)

Figure 14: The difference of OLR (shaded in $\mathrm{W} \mathrm{m} 2^{-1}$ ) and SLP (contour in hPa) in JJAS (a) between El Niño alone years and La Niña alone years, (b) between pIOD alone years and nIOD alone years, and (c) between El Niño and pIOD coexisting and La Niña and nIOD coexisting years.

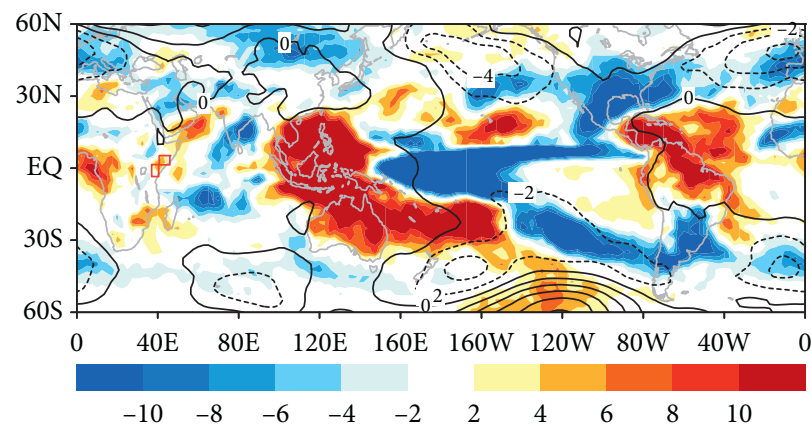

(a)

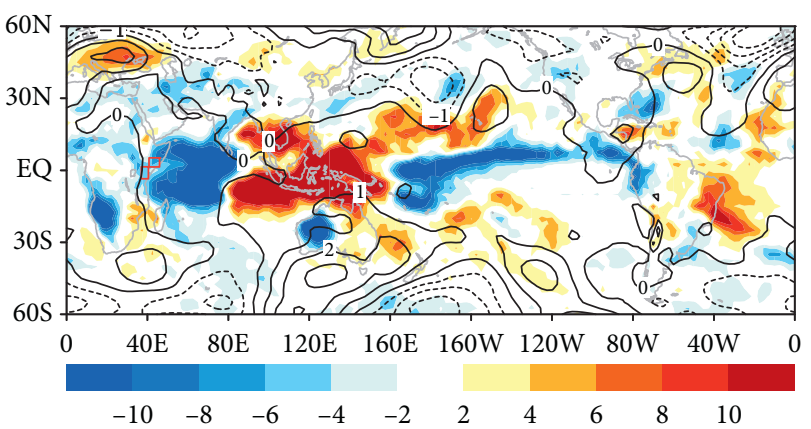

(b)

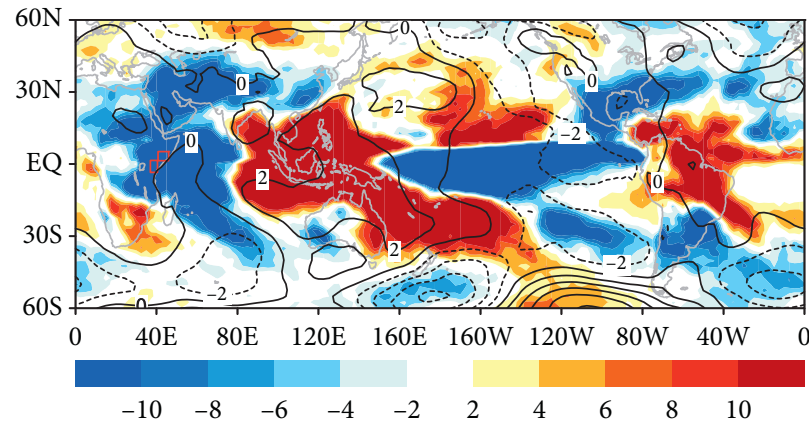

(c)

FIGURE 15: Same as Figure 14, but for OND season. (a) OND OLR and SLP (ENSO alone), (b) OND OLR and SLP (IOD alone), and (c) OND OLR and SLP (both ENSO \& IOD). 


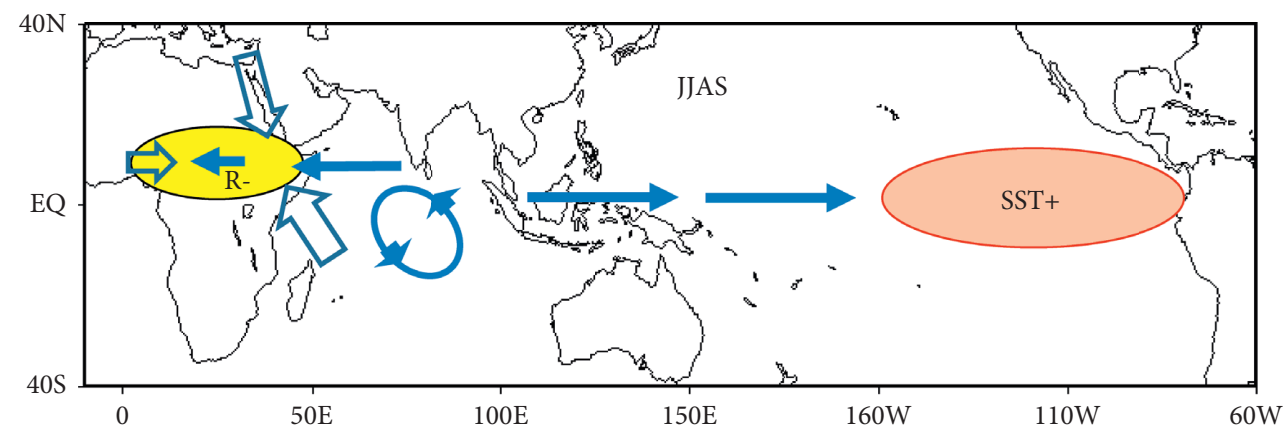

(a)

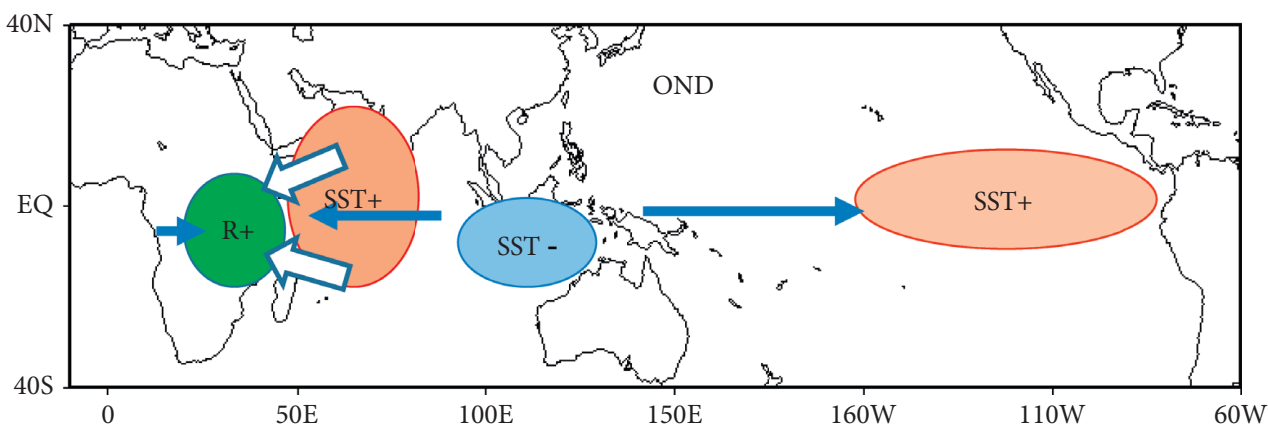

(b)

FIGURE 16: Schematic diagrams showing the relationship of (a) JJAS rainfall and (b) OND rainfall in the GHA with tropical SST. The solid (blank) arrow represents anomalous (climatological) wind at $850 \mathrm{hPa}$. $\mathrm{R}+(\mathrm{R}-)$ marks the positive (negative) rainfall anomalies over the GHA.

related to early-onset ENSO, whereas late-onset ENSO forces a vague IOD pattern with marginal SST anomalies in western IO. The variability of autumn rainfall over equatorial East Africa is more closely related to warm SST over tropical western IO. But, during the co-occurrence of El Niño and positive IOD events, the OND rainfall is more pronounced than that in positive IOD alone events.

\section{Data Availability}

The data used to support the finding of this study are available from the corresponding author upon request.

\section{Conflicts of Interest}

The authors declare that there are no conflicts of interest.

\section{Acknowledgments}

This work has been supported by the National Key Research and Development Program of China (2016YFA0600402). The authors also thank the Ministry of Commerce of People's Republic of China scholarship program.

\section{References}

[1] B. Lu, A. A. Scaife, N. Dunstone et al., "Seasonal predictability of Kiremt rainfall in coupled general circulation models," Environmental Research Letters, vol. 12, p. 114016, 2017.

[2] O. Collins, A. M. Mwanthi, J. B. Mwesigwa, Z. K. K. Atheru, M. A. Wanzala, and G. Artan, "Improved seasonal prediction of rainfall over East Africa for application in agriculture: statistical downscaling of CFSv2 and GFDL-FLOR," Journal of Applied Meteorology and Climatology, vol. 56, no. 12, pp. 3229-3243, 2017.

[3] B. Liebmann, M. P. Hoerling, C. Funk et al., "Understanding recent eastern Horn of Africa rainfall variability and change," Journal of Climate, vol. 27, no. 23, pp. 8630-8645, 2014.

[4] S. E. Nicholson, "The predictability of rainfall over the greater Horn of Africa. Part I: prediction of seasonal rainfall," Journal of Hydrometeorology, vol. 15, no. 3, pp. 1011-1027, 2014.

[5] Z. Owiti, L. A. Ogallo, and J. Mutemi, "Linkages between the Indian Ocean Dipole and east African seasonal rainfall anomalies," Journal of Kenya Meteorology Society, vol. 2, pp. 3-17, 2008.

[6] M. Adnew, D. David, and P. R. Woldeamlak, "Teleconnections between Ethiopian rainfall variability and global SSTs: observations and methods for model evaluation," Meteorology and Atmospheric Physics.vol. 129, no. 2, pp. 173-186, 2017.

[7] W. Yang, R. Seager, M. A. Cane, and B. Lyon, "The annual cycle of East African precipitation," Journal of Climate, vol. 28, no. 6, pp. 2385-2404, 2015.

[8] E. Black, "The relationship between Indian Ocean sea-surface temperature and East African rainfall," Philosophical Transactions of the Royal Society A: Mathematical, Physical and Engineering Sciences, vol. 363, no. 1826, pp. 43-47, 2005.

[9] N. Philippon, P. Camberlin, and N. Fauchereau, "Empirical predictability study of october-december East African rainfall," Quarterly Journal of the Royal Meteorological Society, vol. 128, no. 585, pp. 2239-2256, 2002.

[10] P. Camberlin, "June-september rainfall in north-eastern Africa and atmospheric signals over the tropics: a zonal perspective," International Journal of Climatology, vol. 15, no. 7, pp. 773-783, 1995. 
[11] G. T. Diro, D. I. F. Grimes, and E. Black, "Teleconnections between Ethiopian summer rainfall and sea surface temperature: part I-observation and modelling," Climate Dynamics, vol. 37, no. 1-2, pp. 103-119, 2011.

[12] S. Guo, N. Keenlyside, E. Viste, and D. Korecha, "The El Niño effect on Ethiopian summer rainfall," Climate Dynamics, vol. 49, no. 5-6, pp. 1865-1883, 2017.

[13] M. Indeje, F. H. M. Semazzi, and L. J. Ogallo, "ENSO signals in East African rainfall seasons," International Journal of Climatology, vol. 20, no. 1, pp. 19-46, 2000.

[14] D. Korecha and A. G. Barnston, "Predictability of june-september rainfall in Ethiopia," Monthly Weather Review, vol. 135, no. 2, pp. 628-650, 2007.

[15] B. Preethi, T. P. Sabin, J. A. Adedoyin, and K. Ashok, "Impacts of the ENSO Modoki and other tropical indo-pacific climatedrivers on African rainfall," Scientific Report, vol. 5, pp. 1-14, 2015.

[16] T. K. Bahaga, G. Mengistu Tsidu, F. Kucharski, and G. T. Diro, "Potential predictability of the sea-surface temperature forced equatorial East African short rains interannual variability in the 20th century," Quarterly Journal of the Royal Meteorological Society, vol. 141, no. 686, pp. 16-26, 2015.

[17] I. Harris, P. D. Jones, T. J. Osborn, and D. H. Lister, "Updated high-resolution grids of monthly climatic observations-the CRU TS3.10 Dataset," International Journal of Climatology, vol. 34, no. 3, pp. 623-642, 2014.

[18] B. Bladé and C. A. Smith, "Description of a complete (interpolated) outgoing longwave radiation dataset," Bulletin of the American Meteorological Society, vol. 77, pp. 1275-1277, 1996.

[19] N. A. Rayner, D. E. Parker, E. B. Horton et al., "Global analyses of sea surface temperature, sea ice, and night marine air temperature since the late nineteenth century," Journal of Geophyscial Research, vol. 108, p. 4407, 2003.

[20] E. Kalnay and M. Kanamitsu, "NCEP/NCAR 40-year reanalysis project," Bulletin of the American Meteorological Society, vol. 77, no. 3, pp. 437-471, 1996.

[21] G. Meyers, P. McIntosh, L. Pigot, and M. Pook, "The years of El Niño, La niña, and interactions with the tropical Indian ocean," Journal of Climate, vol. 20, no. 13, pp. 2872-2880, 2007.

[22] N. H. Saji, B. N. Goswami, P. N. Vinayachandran, and T. Yamagata, "A dipole mode in the tropical Indian ocean," Nature, vol. 401, no. 6751, pp. 360-363, 1999.

[23] P. J. Webster, A. M. Moore, J. P. Loschnigg, and R. R. Leben, "Coupled ocean-atmosphere dynamics in the Indian Ocean during 1997-98," Nature, vol. 401, no. 6751, pp. 356-360, 1999.

[24] S. K. Behera, J.-J. Luo, S. Masson et al., "Paramount impact of the Indian Ocean dipole on the East African short rains: a CGCM study," Journal of Climate, vol. 18, no. 21, pp. 4514-4530, 2005.

[25] L. Goddard and N. E. Graham, "Importance of the Indian Ocean for simulating rainfall anomalies over eastern and southern Africa," Journal Geophysical Research, vol. 104, no. D16, pp. 19099-19116, 1999.

[26] M. Latif, D. Dommenget, M. Dima, and A. Grötzner, "The role of Indian ocean sea surface temperature in forcing East African rainfall anomalies during december-january 1997/98," Journal of Climate, vol. 12, no. 12, pp. 3497-3504, 1999.

[27] C. C. Ummenhofer, A. Sen Gupta, M. H. England, and C. J. C. Reason, "Contributions of Indian Ocean sea surface temperatures to enhanced East African rainfall," Journal of Climate, vol. 22, no. 4, pp. 993-1013, 2009.
[28] T. Li, C.-P. Wang, and Y. Zhang, "A theory for the Indian Ocean dipole-zonal mode," Journal of the Atmospheric Sciences, vol. 60, no. 17, pp. 2119-2135, 2003.

[29] T. G. Prasad and J. L. McClean, "Mechanisms for anomalous warming in the western Indian Ocean during dipole mode events," Journal of Geophysical Research, vol. 109, no. C2, p. C02019, 2004.

[30] R. Zhang, T. Li, and M. Wen, "Role of intraseasonal oscillation in asymmetric impacts of El Niño and La Niña on the rainfall over southern China in boreal winter," Climate Dynamics, vol. 45, no. 3-4, pp. 559-567, 2015.

[31] L. Fan, Q. Liu, and C. Wang, "Indian Ocean dipole modes associated with different types of ENSO development," Journal of Climate, vol. 30, no. 6, pp. 2233-2249, 2017. 